Published in final edited form as:

J Am Chem Soc. 2016 September 14; 138(36): 11979-11988. doi:10.1021/jacs.6b07165.

\title{
A Crystallographic Examination of Predisposition versus Preorganization in de Novo Designed Metalloproteins
}

\author{
Leela Ruckthong ${ }^{\dagger, \ddagger}$, Melissa L. Zastrow ${ }^{\dagger, \|}$, Jeanne A. Stuckey ${ }^{\star}, \S$, and Vincent L. \\ Pecoraro ${ }^{*}, t, \neq$ \\ †Department of Chemistry, University of Michigan, Ann Arbor, Michigan 48109, United States \\ ‡Biophysics Program, University of Michigan, Ann Arbor, Michigan 48109, United States \\ §ife Sciences Institute, University of Michigan, Ann Arbor, Michigan 48109, United States
}

\begin{abstract}
Preorganization and predisposition are important molecular recognition concepts exploited by nature to obtain site-specific and selective metal binding to proteins. While native structures containing an $\mathrm{MS}_{3}$ core are often unavailable in both apo- and holo-forms, one can use designed three-stranded coiled coils (3SCCs) containing tris-thiolate sites to evaluate these concepts. We show that the preferred metal geometry dictates the degree to which the cysteine rotamers change upon metal complexation. The Cys ligands in the apo-form are preorganized for binding trigonal pyramidal species $\left(\mathrm{Pb}(\mathrm{II}) \mathrm{S}_{3}\right.$ and $\left.\mathrm{As}(\mathrm{III}) \mathrm{S}_{3}\right)$ in an endo conformation oriented toward the 3SCC Ctermini, whereas the cysteines are predisposed for trigonal planar $\mathrm{Hg}(\mathrm{II}) \mathrm{S}_{3}$ and 4-coordinate $\mathrm{Zn}(\mathrm{II}) \mathrm{S}_{3} \mathrm{O}$ structures, requiring significant thiol rotation for metal binding. This study allows assessment of the importance of protein fold and side-chain reorientation for achieving metal selectivity in human retrotransposons and metalloregulatory proteins.
\end{abstract}

\section{Graphical abstract}

\footnotetext{
“Corresponding Authors: jass@umich.edu, vlpec@umich.edu.

"Present Address: Department of Chemistry, Massachusetts Institute of Technology, 77 Massachusetts Avenue, 18-444, Cambridge, Massachusetts 02139, United States.

Supporting Information

The Supporting Information is available free of charge on the ACS Publications website at DOI: 10.1021/jacs.6b07165.

Tables S1 and S2, data collection and refinement statistics of all structures; Figure S1, sequence of the ORF1 protein from the human LINE1 retrotransposon based on the Uniprot ID: Q9UN81; Figure S2, the orientations of Cys side chains in the 16th layer of apo(CSL16C)3; Figure S3, the similarity of the major Cys conformer orientation in apo-(CSL16C) 3 and apo-(CSL9C) 3 structures; Figure S4, a high level of preorganization of Pen ligands toward a trigonal planar $\mathrm{Hg}$ (II)-binding site in 3SCC peptides; Figure S5, an alignment of the helical backbones between $\mathrm{Hg}(\mathrm{II}) \mathrm{SZn}-(\mathrm{II}) \mathrm{N}(\mathrm{GRAND}-\mathrm{CSL} 16 \mathrm{CL} 30 \mathrm{H}) 3^{+}$and $\mathrm{Zn}(\mathrm{II})\left(\mathrm{H}_{2} \mathrm{O}\right)(\mathrm{GRAND}-$

CSL12AL16C) $3^{-}$; Figure S6, ribbon diagrams comparing the number of observed waters in the cavities above the trigonal planar sites when the second coordination sphere at the 12th position is replaced with Ala versus Leu; Figure S7, ribbon diagrams comparing trigonal planar $\mathrm{Hg}(\mathrm{II}) \mathrm{S}_{3}$ and 4-coordinate $\mathrm{Zn}(\mathrm{II}) \mathrm{S}_{3}\left(\mathrm{H}_{2} \mathrm{O}\right)$ metal sites; Figure S8, ribbon diagrams showing the interlayer spacing around the apo and metalated Cys3 site in designed 3SCC structures; Figure S9, comparison of endo versus exo configurations of $\mathrm{Pb}(\mathrm{II}) \mathrm{S}_{3}$ in $\mathrm{Pb}(\mathrm{II}) \mathrm{SZn}(\mathrm{II}) \mathrm{N}(\mathrm{GRAND}-\mathrm{CSL} 16 \mathrm{CL} 30 \mathrm{H}) 3_{3}{ }^{+}$and native ALAD; and Figure S10, packing comparison of Leu residues in metalated trigonal pyramidal structures versus the apo-structure demonstrating the extent of hydrophobic packing below metal binding sites (PDF)

Notes

The authors declare no competing financial interest.
} 


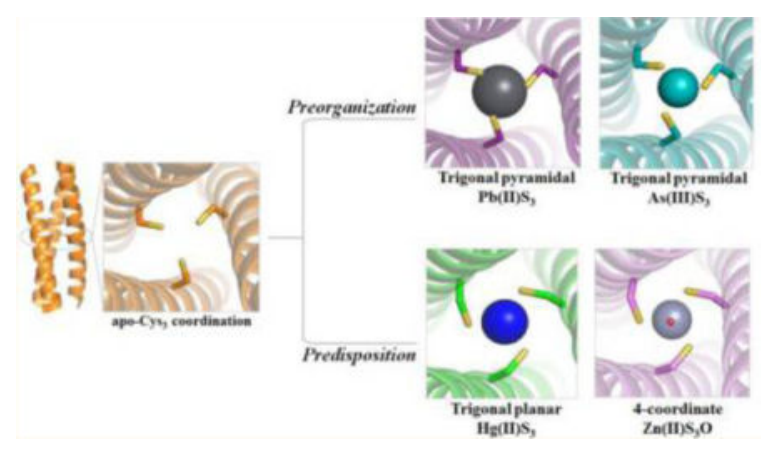

\section{INTRODUCTION}

Thiolate-rich ligands are used in several biological systems to interact with heavy metals. Prokaryotes employ metalloregulatory proteins to control the level of essential and toxic metals in cells. ${ }^{1-5}$ Often Cys-rich, these proteins function at the transcriptional level as metal sensors that regulate the expression of numerous gene products for overseeing proper metal ion homeostasis or detoxification. Two distinct classes of these metalloregulators are the MerR and SmtB/ArsR families. ${ }^{2,3}$ MerR proteins function as repressors in the absence of metals and become activators upon metal binding, ${ }^{6}$ whereas $\mathrm{SmtB} / \mathrm{ArsR}$ proteins are classic repressors. ${ }^{3}$ MerR itself has a strong selectivity for $\mathrm{Hg}(\mathrm{II}),{ }^{8}$ but some MerR family proteins (e.g., PbrR, CueR, and ZntR) can discriminate against other metals. ${ }^{2}$ Spectroscopic and sitedirected mutagenesis studies suggest that these proteins bind target metals into specific coordination geometries. MerR binds $\mathrm{Hg}$ (II) with a trigonal planar structure using three Cys residues, $1,6,7,9-11$ whereas a $\mathrm{Pb}(\mathrm{II}) \mathrm{S}_{3}$ site forms in PbrR691 with a hemidirected trigonal pyramidal geometry. ${ }^{5}$ The transcriptional repressor ArsR is proposed to bind As(III) in a trigonal pyramid. ${ }^{3}$ Heavy metals exploit the same basic chemistry to interfere with biological binding sites that contain Cys ligands. One well-known example is $\mathrm{Pb}$ (II) substitution in the $\mathrm{Zn}(\mathrm{II})$-dependent enzyme $\delta$-aminolevulinic acid dehydratase (ALAD), which catalyzes the second step of the heme biosynthetic pathway. ${ }^{12}$ Inhibition of this enzyme is thought to cause $\mathrm{Pb}$ (II)-related anemia and neurological symptoms. $\mathrm{Pb}$ (II) inhibits ALAD by replacing the native pseudo tetrahedral $\mathrm{Zn}(\mathrm{II}) \mathrm{S}_{3} \mathrm{O}$ site with $\mathrm{Pb}(\mathrm{II}) \mathrm{S}_{3}$ in a trigonal pyramidal geometry. ${ }^{13,14}$

The structure of the human Line-1 retrotransposon is of particular interest to this study.

Retrotransposons increase the variability of the human genome. The Line-1 element contains two open reading frames, one of which (ORF1) encodes a sequence that may be an RNA packaging protein. ${ }^{15,16}$ It includes an N-terminal sequence that utilizes a heptad repeat with hydrophobes in the $a$ and $d$ positions and trimerizes to form a three-stranded coiled coil (3SCC) that appears essential for proper activity. There are two very interesting aspects of this coiled coil structure that relate to bound ions. First, chloride appears to stabilize the fold at two positions that have either glycine (a) and arginine $(d)$ in adjacent layers or a position that has asparagine (d). Second, there are hydrophobic layers substituted by cysteine in $a$ and $d$ positions, as shown in the sequence in Figure S1, that are excellent binding motifs for heavy metal cations such as $\mathrm{Hg}(\mathrm{II})$ and $\mathrm{Pb}(\mathrm{II})$. Thus, a here-to-fore unrecognized potential 
target for heavy metal effects on the human genome may be the change in dynamics of the $3 \mathrm{SCC}$ due to the strong $\mathrm{M}-\mathrm{S}$ bonds.

Metal binding to three Cys ligands is the core feature of these examples. Thus, studying how the $\mathrm{Cys}_{3}$ ligand set adopts to varied metal geometries, within different protein folds, is critical for assessing metal specificity and selectivity in natural systems. To achieve this level of understanding, structural characterization of both apo- and metalated protein forms is required.

Synthetic biology is an effective tool for elucidating native protein function. One strategy is de novo metalloprotein and metalloenzyme design. ${ }^{17-21}$ The controllable incorporation of metals into designed scaffolds provides an understanding of the interplay between amino acid side chains, coordination number, and polyhedral preference of different cations. We use designed 3SCCs containing thiol residues for chelating metals in geometries relevant for understanding heavy metal interactions in proteins. These 3SCCs exploit a heptad motif strategy previously described for the design of CoilSer and $\mathrm{V}_{\mathrm{a}} \mathrm{L}_{\mathrm{d}}$ peptides reported by DeGrado. ${ }^{22,23}$ The TRI and GRAND peptide sequences use the heptad repeat $\mathrm{L}_{\mathrm{a}} \mathrm{K}_{\mathrm{b}} \mathrm{A}_{\mathrm{c}} \mathrm{L}_{\mathrm{d}} \mathrm{E}_{\mathrm{e}} \mathrm{E}_{\mathrm{f}} \mathrm{K}_{\mathrm{g}}$ (Table 1). ${ }^{24}$ Using these peptides, we generated a heavy metal binding site by substituting cysteine for leucine in either the first $(a)$ or the fourth $(d)$ position of one heptad. Adding $\mathrm{Hg}$ (II) to (TRIL16C) ${ }_{3}$ led to $\mathrm{Hg}(\mathrm{II})(\mathrm{TRIL16C})_{3}{ }^{-}$, the first water-soluble model of a trigonal planar $\mathrm{Hg}(\mathrm{II})$ site for MerR. ${ }^{25-27}$ Moreover, $\mathrm{Cys}_{3}$-substituted 3SCCs can bind other heavy metals, including $\mathrm{Pb}(\mathrm{II}), \mathrm{Cd}(\mathrm{II}), \mathrm{As}(\mathrm{III}), \mathrm{Bi}(\mathrm{III})$, and $\mathrm{Zn}(\mathrm{II}) .{ }^{25-36}$ Despite significant success in spectroscopically characterizing metalated 3SCCs to elucidate metalprotein interactions in aqueous solution, the structural details of these systems remained elusive.

To optimize the predictive ability for binding metals within these scaffolds, and to understand how native proteins achieve metal selectivity, one must define the extent of predisposition versus preorganization of the apo-proteins for the target metal. Here, we define predisposition as the placement of ligands at an appropriate layer to complex a metal, whereas a preorganized site not only contains the requisite numbers and types of heteroatoms in a layer, but in addition requires no, or minimal, reorganization of the protein side chains when complexing the desired target. One can imagine that preorganizing a site for a specific coordination geometry can lead to selectivity of metal binding either for distinguishing different metals at the same binding site or for discrimination of different sites ( $a$ vs $d$ ) within an individual scaffold. Structural information is required to evaluate the extent of site preorganization for metal binding proteins. There are numerous examples of preorganized metal binding sites in proteins. ${ }^{37}$ Both the electron transfer blue copper protein and the zinc-dependent hydratase carbonic anhydrase are highly preorganized for metal binding. ${ }^{38-40}$ In contrast, proteins such as zinc fingers are neither preorganized nor predisposed for metal binding. Systems such as the designed protein Dueferri 1 (DF1) or $\mathrm{Zn}(\mathrm{II})$-bound metalloregulators SmtB/ArsR and CadC appear to be intermediate between these extremes. ${ }^{41-43}$ The level of molecular recognition exhibited by apo-MerR and metalated MerR indicates that neither preorganized nor even predisposed metal sites for $\mathrm{Hg}$ (II) binding exist. ${ }^{44}$ 
Because both TRI and GRAND peptide sequences have not been amenable for growing Xray quality single crystals, we have utilized CoilSer peptides (CS or GRAND-CS) that contain cysteine or histidine substitutions in the helical core. These analogues behave spectroscopically and functionally identically to the corresponding TRI and GRAND peptides; ${ }^{45}$ however, the CS and GRAND-CS peptides contain a histidine in the $f$ position of the last heptad. These His residues are present on the exterior of the $3 \mathrm{SCC}$ and can form, between bundles, a $\mathrm{Zn}$ (II) binding site that links individual scaffolds to generate wellstructured single crystals. Therefore, metal site design strategies can be evaluated by comparing the structures of apo versus metalated CS and GRAND-CS peptides. In this report, we address the extent of sulfur layer complexation for binding $\mathrm{Pb}$ (II), $\mathrm{As}$ (III), $\mathrm{Hg}$ (II), and $\mathrm{Zn}(\mathrm{II})$ in a position cysteine-substituted peptides.

With this detailed structural study, we explore how the metal binding structures observed correlate with metal geometry preferences. Importantly, these designed systems allow us to address active site preorganization exclusively, without complications associated with other protein conformational changes. We find that Cys residues in 3SCCs are predisposed for binding metals that prefer trigonal planar $\left(\mathrm{Hg}(\mathrm{II}) \mathrm{S}_{3}\right)$ and pseudo tetrahedral $\left(\mathrm{Zn}(\mathrm{II}) \mathrm{S}_{3} \mathrm{O}\right)$ geometries, but are preorganized for binding trigonal pyramidal metals ( $\mathrm{Pb}$ (II) and $\mathrm{As}(\mathrm{III})$ ), regardless of size or charge. Furthermore, packing in the second coordination sphere plays an important role in determining preorganization versus predisposition for $\mathrm{Zn}(\mathrm{II}), \mathrm{Pb}$ (II), and As(III) sites. Thus, we provide the first systematic study defining the role of active site preorganization in helical assemblies, which should aid in both unraveling the molecular basis for heavy metal recognition and defining general rules for metal selectivity observed in biological systems.

\section{RESULTS AND DISCUSSION}

\section{Cys Arrangement in the Apo-Structure}

The crystal structure of apo-(CSL16C) 3 provides the Cys arrangement when a metal is not bound to the site (Figure S2). The major conformation for the three cysteine side chains, considered as a single unit, is based on the major $\mathrm{S} \gamma$ conformers (60\% occupancy) of two chains combined with the third Cys from the other (70\% occupancy). Thus, approximately $25 \%$ of the time (Table S3), all of the ligands are directed toward the helical core with an average $\mathrm{S} \gamma-\mathrm{S} \gamma$ distance of $3.32 \AA$ (average $\chi 1$ of Cys $=-66.24^{\circ}$ ) (Figure 1a). This same Cys arrangement was observed in the major $\mathrm{S} \gamma$ conformers (average $\chi 1$ of Cys $=-70.52^{\circ}$ and average $\mathrm{S} \gamma-\mathrm{S} \gamma$ distance of $3.32 \AA$ ) of the published apo-(CSL9C) $)_{3}$ structure, which has the Cys residues in the ninth position (a site) (Figure S3). ${ }^{46}$ These structures suggest that Cys layers at a sites generate analogous apo cysteine major conformations. In addition to these two conformations, multiple combinations of the two conformers are possible. $45 \%$ of the conformations have two of the conformers directed to the helical core. Thus, we may conclude that $70 \%$ of the sites are fully or significantly preorganized for lead or arsenic binding. The remaining 30\% have at least two of the Cys residues oriented outward to the helical interface. With this in mind, only the major conformation will be discussed further to represent the apo-coordination in the 3SCC peptides. One can imagine that native proteins, which utilize hydrogen-bonding residues to the sulfur atoms, would constrain such sites into 
single conformations. All crystallographic parameters determined from the structures are listed in Table 2.

\section{Structural Analysis of Trigonal Planar $\mathrm{Hg}(\mathrm{II}) \mathrm{S}_{3}$ Binding in 3SCC Peptides}

With a $3.32 \AA \mathrm{S} \gamma-\mathrm{S} \gamma$ distance, the major Cys conformation in apo-(CSL16C) $)_{3}$ would require a M-S distance of $\sim 1.90 \AA$ to accommodate a metal within the three sulfur atom plane. ${ }^{47}$ This distance is unrealistically short for a 3 -coordinate $\mathrm{Hg}(\mathrm{II})-\mathrm{S}$ bond and most other heavy metal-sulfur bonds. Thus, a trigonal planar geometry as in MerR must impart some degree of cysteine side-chain rearrangement. Koch demonstrated that simple $\mathrm{Hg}$ (II) $(\mathrm{SR})_{3}{ }^{-}$complexes have $2.44 \AA \mathrm{Ag}(\mathrm{II})-\mathrm{S}$ distances and $4.19 \AA \mathrm{A} \gamma-\mathrm{S} \gamma$ separations. ${ }^{48,49}$ The $\mathrm{Hg}(\mathrm{II})-\mathrm{S}$ distances in $\mathrm{Hg}(\mathrm{II})_{\mathrm{S}} \mathrm{Zn}(\mathrm{II}) \mathrm{N}\left(\right.$ GRAND-CSL16CL30H) ${ }_{3}{ }^{+}$and $\mathrm{MerR}^{9,10}$ match these parameters. Overlaying the trigonal $\mathrm{Hg}(\mathrm{II}) \mathrm{S}_{3}$ site (Figure 1c, d) from $\mathrm{Hg}(\mathrm{II})_{\mathrm{S}} \mathrm{Zn}(\mathrm{II})_{\mathrm{N}}(\mathrm{GRAND}-\mathrm{CSL} 16 \mathrm{CL} 30 \mathrm{H})_{3}{ }^{+}$onto the $\mathrm{Cys}_{3}$ site in apo- $(\mathrm{CSL} 16 \mathrm{C})_{3}(\mathrm{rmsd}=$ $0.510)$ confirms the different Cys orientations expected between the two structures. Thus, fitting a $\mathrm{Hg}$ (II) ion into the metal binding plane requires the thiols in the apoprotein to reorient for the trigonal planar structure, and is accomplished by moving the core- and $\mathrm{N}$ termini-directed cysteine sulfur atoms (in the absence of metal, $\chi 1$ of $-66.24^{\circ}$ ) to face out to the helical interface and "down" toward the C-termini (in the presence of metal, $\chi 1$ of $-150.35^{\circ}$ ). This rearrangement expands the $\mathrm{S} \gamma-\mathrm{S} \gamma$ distance from $3.32 \AA$ in apo-(CSL16C) 3 to $4.08 \AA$, affording the additional space required to accept the large $\mathrm{Hg}(\mathrm{II})$ ion (ionic radius $=1.16 \AA)^{50}$ into the trigonal plane with a $\mathrm{Hg}(\mathrm{II})-\mathrm{S}$ distance of $2.38 \AA$, which is in close agreement with the $2.43 \AA$ distance obtained through EXAFS spectroscopy. ${ }^{27}$ The structure corroborates the previously published trigonal thiolate $\mathrm{Hg}(\mathrm{II})$ assignment $^{26,27,29,45}$ for $\mathrm{Hg}$ (II)(TRIL16C) ${ }_{3}{ }^{-}$at $\mathrm{pH} 8.5$ and provides a higher resolution crystallographic model of the active site of the trigonal planar $\mathrm{Hg}$ (II)-bound MerR protein. ${ }^{44}$ Overall, we conclude that the apo-Cys coordination is predisposed, but not preorganized toward a trigonal planar $\mathrm{Hg}$ (II) complex.

No global rearrangement or significant distortions of the helices are required upon $\mathrm{Hg}$ (II) binding, indicating that the $3 \mathrm{SCC}$ framework qualifies as a rigid scaffold that interrogates solely the metal chelation preferences in these designed proteins. This is in marked contrast with the native metalloregulator MerR proteins, which use the loop region to bind to the metal and effect major protein conformational changes. ${ }^{44}$ Despite these differences in the apo-proteins, within the precision of the refinements for both metalated systems (based on the resolution and $R$ values), ${ }^{51}$ both structures display indistinguishable trigonal binding sites $\left(\mathrm{S} \gamma-\mathrm{S} \gamma\right.$ separations of $4.08 \AA$ for $\mathrm{Hg}(\mathrm{II})_{\mathrm{S}} \mathrm{Zn}(\mathrm{II})_{\mathrm{N}}(\mathrm{GRAND}-\mathrm{CSL} 16 \mathrm{CL} 30 \mathrm{H})_{3}{ }^{+}$and 4.24 $\AA$ for the native protein ${ }^{44}$ ). As a result, the $\mathrm{Hg}(\mathrm{II})-\mathrm{S}$ bond length in the designed structure $(2.38 \AA)$ is in excellent agreement with the $2.44 \AA$ bond length in the MerR crystal structure. ${ }^{44}$ This comparison demonstrates that regardless of the initial apoprotein structure, the final metal site must conform to the same geometric restrictions. However, examination of the microenvironment at the Cys ligands of both structures highlights that the residues have different through-space orientations (Figure 2), indicating that to achieve a trigonal binding site, the rotamers must be positioned differently in the distinct structures. The wide range of Cys torsion angles $\left(-69.33^{\circ}\right.$, Cys79; $173.45^{\circ}$, Cys112; and $173.68^{\circ}$, Cys 127) observed in the native protein reflects the flexibility of the ligands located in the loop region, 
but the three Cys ligands in the designed protein are restricted to the 3 -fold symmetric coiled coil environment with $\chi 1$ of $-150.35^{\circ}$. Given the markedly different Cys torsion angles, the fact that the two divergent systems retain similar spectroscopic signatures is impressive. Most important, these observations demonstrate that forming a trigonal planar $\mathrm{Hg}(\mathrm{II}) \mathrm{S}_{3}$ site within $a$-helical bundles, as found in other metalloregulatory proteins, would not allow the necessary global conformational changes required for proper MerR function.

It is surprisingly straightforward to change this binding site from one that is simply predisposed to one that exhibits a high degree of ligand preorganization. We have previously reported the structures of apo-(CSL16Pen $)_{3}$ and $[\mathrm{Hg}(\mathrm{II})]_{\mathrm{s}}\left[\mathrm{Zn}(\mathrm{II})-\left(\mathrm{H}_{2} \mathrm{O} /\right.\right.$

$\left.\left.\mathrm{OH}^{-}\right)\right]_{\mathrm{N}}(\mathrm{CSL} 9 \mathrm{PenL} 23 \mathrm{H})_{3}{ }^{n+}$ in which cysteine residues have been substituted with penicillamine (Pen). ${ }^{31,32}$ The side-chain of Pen differs from that of Cys by introducing a germinal dimethyl substitution at the $\beta$-carbon of the Cys residue. The $\mathrm{Hg}(\mathrm{II})$ ion retains the same trigonal planar geometry; however, the apoprotein has markedly different conformations for the side-chain dihedral angles than those observed for cysteine residues in the apoprotein. The thiols in the Pen-substituted apoprotein do not need to change significantly to accept a trigonal planar structure (average apo $\chi 1$ of $-49.85^{\circ}$, metalated $\chi 1$ of $-50.23^{\circ}$ ) (Figure S4). Thus, we can convert a site that was only predisposed to bind $\mathrm{Hg}$ (II) into one that is highly preorganized for $\mathrm{Hg}$ (II) sequestration via the simple expedient of adding two methyl groups to the side chain in 3SCCs.

\section{Structural Description of 4-Coordinate Zn(II)-Binding 3SCCs}

We prepared a $\mathrm{Zn}(\mathrm{II}) \mathrm{S}_{3} \mathrm{O}$ site using the GRAND-CSL12A16C peptide. The L12AL16C variant was originally designed to provide additional space for solvent molecules to bind to the metal center at the 16Cys site by substituting Leu for Ala in the 12th position. ${ }^{35,36} \mathrm{An}$ overlay of (GRAND-CSL12A16C) $)_{3}$ and (GRAND-CSL16CL30H) 3 backbone structures in Figure $\mathrm{S} 5$ demonstrates that alanine substitution does not significantly alter the overall assembly. The $\mathrm{Zn}(\mathrm{II})\left(\mathrm{H}_{2} \mathrm{O}\right)$ (GRAND-CSL12A16C) ${ }_{3}{ }^{-}$structure has three $\mathrm{Zn}(\mathrm{II})-$ coordinating Cys ligands with an exogenous water to complete 4-coordination. The 12Ala layer generates a void space above the metal site, which is sufficient for excess waters as can be seen in the related crystal structure for $\mathrm{Hg}(\mathrm{II})\left(\right.$ GRAND-CSL12A16C) ${ }_{3}{ }^{-}$(Figure S6a, b) ${ }^{52} \mathrm{An}$ attempt to model these waters did not provide crystallographically reasonable results, indicating that the solvents in this void are not rigidly held at specific positions. However, this cavity is larger than the corresponding interlayer space made by 12Leu in $\mathrm{Hg}(\mathrm{II})_{\mathrm{S}} \mathrm{Zn}-(\mathrm{II})_{\mathrm{N}}(\mathrm{GRAND}-\mathrm{CSL} 16 \mathrm{CL} 30 \mathrm{H})_{3}{ }^{+}$where only one water is observed (Figure S6c, d). The conformations of the 3-fold related Cys ligands of $\mathrm{Zn}(\mathrm{II})\left(\mathrm{H}_{2} \mathrm{O}\right)($ GRANDCSL12A16C $)_{3}{ }^{-}$are similar, but not identical, to those observed for trigonal planar $\mathrm{Hg}(\mathrm{II}) \mathrm{S}_{3}$ in $\mathrm{Hg}(\mathrm{II})_{\mathrm{S}} \mathrm{Zn}(\mathrm{II})_{\mathrm{N}}(\mathrm{GRAND}-\mathrm{CSL} 16 \mathrm{CL} 30 \mathrm{H})_{3}{ }^{+}$(Figure S7). We conclude that metal chelation for $\mathrm{Zn}$ (II) is also associated with a predisposed, but not preorganized, apo-3SCC (Figure 3). The $\chi 1$ torsion angles of the two structures are close in value ( $\chi 1$ of $-149.39^{\circ}$ for $\mathrm{Zn}(\mathrm{II}) \mathrm{S}_{3} \mathrm{O}$ and $\chi 1$ of $-150.35^{\circ}$ for $\left.\mathrm{Hg}(\mathrm{II}) \mathrm{S}_{3}\right)$; however, the decreased dihedral angle in $\mathrm{Zn}(\mathrm{II})-\left(\mathrm{H}_{2} \mathrm{O}\right)$ (GRAND-CSL12A16C) ${ }_{3}{ }^{-}$causes a shorter $\mathrm{S} \gamma-\mathrm{S} \gamma$ separation (3.92 $\AA$ ) verifying that the sulfur plane of the $\mathrm{Zn}$ (II) coordination site is smaller than the trigonal planar $\mathrm{Hg}(\mathrm{II}) \mathrm{S}_{3}$ (4.08 $\AA$ ). The $\mathrm{Zn}(\mathrm{II})$ structure is distorted pseudo tetrahedral, with angles of $\mathrm{S}-\mathrm{Zn}(\mathrm{II})-\mathrm{S}$ and $\mathrm{S}-$ $\mathrm{Zn}(\mathrm{II})-\mathrm{O}$ that are not perfectly at $109.5^{\circ}$. $\mathrm{Zn}$ (II) sits close to the sulfur plane, with a 
surprisingly small out-of-plane distance of $0.20 \AA$ toward the water ligand as compared to $\mathrm{Hg}$ (II) in the trigonal planar $\mathrm{Hg}(\mathrm{II}) \mathrm{S}_{3}$ site $(0.30 \AA$ below the plane). This difference may be a consequence of shorter $\mathrm{Zn}(\mathrm{II})-\mathrm{S}$ bonds ( $2.27 \AA$ ), which do not require the thiols to open as much as for the larger $\mathrm{Hg}$ (II) ion. Another factor that distinguishes $\mathrm{Zn}$ (II) from $\mathrm{Hg}$ (II) is a preference for 4-coordinate over 3-coordinate geometry. The $\mathrm{Zn}(\mathrm{II})-\mathrm{O}$ distance is $2.18 \AA$, reflective of a real coordinative bond; however, the uncoordinated water above the $\mathrm{Hg}$ (II)S $\mathrm{S}_{3}$ site in $\mathrm{Hg}(\mathrm{II})_{\mathrm{S}} \mathrm{Zn}(\mathrm{II})_{\mathrm{N}}(\mathrm{GRAND}-\mathrm{CSL} 16 \mathrm{CL} 30 \mathrm{H})_{3}{ }^{+}$is $2.79 \AA$ away from $\mathrm{Hg}(\mathrm{II})$, a distance that is too long to represent a $\mathrm{Hg}(\mathrm{II})-\mathrm{O}$ bond (typically 2.20-2.30 ̊) (Figure S6d). ${ }^{53,54} \mathrm{~A}$ very important observation for both the $\mathrm{Hg}$ (II) and the $\mathrm{Zn}$ (II) structures is that the solvents are only found in the interlayer spacing toward the $\mathrm{N}$-termini, not the $\mathrm{C}$-termini, of the 3SCC (Figure S8). This is because the interlayer spacing on going from $a$ to $d$ residues is smaller $(\sim 41 \AA$ ) than on progressing from $d$ to $a$ in the sequence $(\sim 4.92 \AA)$. Additionally, reorientation of the Cys layer toward the C-termini upon $\mathrm{Hg}$ (II) and $\mathrm{Zn}$ (II) binding makes the interlayer space below ( $a$ to $d$ ) the metal site even smaller.

\section{Trigonal Pyramidal Coordination in 3SCC Environments}

The binding of trigonal pyramidal ions is markedly different from that of trigonal planar or pseudo tetrahedral species. Unlike the trigonal $\mathrm{Hg}(\mathrm{II}) \mathrm{S}_{3}$ structure with the Cys thiols pointing outward toward the helical interface $\left(\chi 1\right.$ of $\left.-150.35^{\circ}\right)$, the corresponding rotamers in $\mathrm{Pb}(\mathrm{II})_{\mathrm{S}} \mathrm{Zn}-(\mathrm{II})_{\mathrm{N}}(\mathrm{GRAND}-\mathrm{CSL} 16 \mathrm{CL} 30 \mathrm{H})_{3}{ }^{+}$are directed toward the core and $\mathrm{N}$-termini of the 3SCC with $\chi^{1}$ of $-68.34^{\circ}$. This $\chi^{1}$ angle is close to the $-66.24^{\circ}$ angle observed in the major conformation of apo-(CSL16C) $)_{3}$, implying that the Cys orientation in the apo-peptide is highly preorganized for a trigonal pyramidal structure (Figure 4). Furthermore, the $\mathrm{S} \gamma-\mathrm{S} \gamma$ separations are similar for apo-(CSL16C) $)_{3}(3.32 \AA)$ and $\mathrm{Pb}(\mathrm{II}) \mathrm{S}_{3}$ in $\mathrm{Pb}$ (II) $)_{\mathrm{S}} \mathrm{Zn}(\mathrm{II})_{\mathrm{N}}(\text { GRAND-CSL16CL30H })_{3}{ }^{+}(3.45 \AA$ ) because $\mathrm{Pb}$-(II) is bound in an endoconfiguration, ${ }^{55}$ which allows the metal to sit $1.63 \AA$ below the sulfur plane toward the Ctermini of the $3 \mathrm{SCC}$. The $\mathrm{Pb}(\mathrm{II})-\mathrm{S}$ bond distance is $2.60 \AA$, which is within the experimental error of values determined for Pb-(TRIL16C) ${ }_{3}{ }^{-}(2.63 \AA \text {, EXAFS })^{29}$ and small inorganic $\mathrm{Pb}(\mathrm{II}) \mathrm{S}_{3}$ complexes. ${ }^{56,57}$ A similar geometry was previously observed in the $\mathrm{As}(\mathrm{III}) \mathrm{S}_{3}$ site of As(III)(CSL9C) $)_{3} \cdot{ }^{58}$ Like $\mathrm{Pb}(\mathrm{II}) \mathrm{S}_{3}$, trivalent arsenic takes on a hemidirected, homoleptic structure in the 3SCC, but due to the smaller radius of As(III) (0.72 $\AA$ ), the As(III)-S distances (average of $2.28 \AA$ ) are significantly shorter than those observed in the $\mathrm{Pb}$ (II) system. Despite the shorter $\mathrm{As}(\mathrm{III})-\mathrm{S}$ distance and higher ionic charge than $\mathrm{Pb}$ (II), $\mathrm{As}(\mathrm{III})$ $(\mathrm{CSL} 9 \mathrm{C})_{3}$ has an average $\chi^{1}\left(-59.66^{\circ}\right)$ and $\mathrm{S} \gamma-\mathrm{S} \gamma$ separation $(3.25 \AA)$ close to those of both the $\mathrm{Pb}$ (II) and the apo-structures. The small size of As(III) requires the thiol ligands to rotate slightly more inward to the core as compared to the apo-proteins (apo-(CSL16C) 3 and apo-(CSL9C $)_{3}$ ), compressing the diameter of the sulfur plane. In contrast, $\mathrm{Pb}$ (II) causes the thiols to move slightly outward from the core due to its larger $1.33 \AA$ atomic radius. The smaller As(III) ion is situated $1.30 \AA$ below the three atom sulfur plane, while the corresponding distance is $1.63 \AA$ in the $\mathrm{Pb}(\mathrm{II}) \mathrm{S}_{3}$ site (Figure 5). Thus, these 3SCCs are preorganized for the binding of trigonal pyramidal ions in the a sites regardless of ion size or charge and can adapt to a significant range of $\mathrm{M}-\mathrm{S}$ distances.

Touw et al. suggested that the lone pair of As(III) may play an important role in influencing As(III) orientation within the $3 \mathrm{SCC} .{ }^{58}$ It was reasoned that As(III) was directed toward the 
C-termini (endo conformation) to accommodate its lone pair because the 12Leu residues located one hydrophobic layer below the 9Cys As(III)-binding site are less tightly packed than the 5Leu residues situated one layer above. The new structure presented herein shows that $\mathrm{Pb}$ (II) binds similarly to As(III) in this tris-thiolate site (Figure 5). Once again, the $\mathrm{Pb}$ (II) stereochemically active lone pair could define orientation; however, given the larger size of $\mathrm{Pb}(\mathrm{II})$, its greater out-of-plane displacement, and the small interlayer separation between the $a$ and $d$ layers, an alternate explanation may be preferable. An equal, or more significant, factor for the observed metal location may be the high level of preorganization of the apo-Cys proteins. An exo configuration for $\mathrm{Pb}(\mathrm{II}) \mathrm{S}_{3}$ was predicted on the basis of structures of small molecule models, a $\mathrm{Pb}$ (II)-bound ALAD protein structure, ${ }^{14}$ and a computational study ${ }^{30}$ that further corroborated this structural preference. However, the observed endo conformation contradicts these precedents. The dominant factor controlling trigonal pyramidal metal structure in CS and GRAND-CS peptides is likely the preferred side-chain rotamer orientation that does not allow the cysteines to be positioned so that $\mathrm{Pb}(\mathrm{II})$ can bind in an exo conformation within the 3SCC.

Helical systems should have similar torsion angle restrictions for cysteines, whereas other secondary or tertiary structures may be able to accept the exo tris-thiolate $\mathrm{Pb}(\mathrm{II})$ complexes (Figure S9). The active site of yeast ALAD, which features a TIM-barrel, is located in a loop connecting $\beta 5$ with $a 4$ at the $\mathrm{C}$-terminal end of the $\beta$-barrel. ${ }^{59}$ The three bound Cys rotamers are directed to the solvent accessible area with varied dihedral angles $\left(-142.7^{\circ}\right.$, Cys133; $41.4^{\circ}$, Cys135; and $-53.2^{\circ}$, Cys 143), allowing for an exo $\mathrm{Pb}(\mathrm{II})$ configuration. ${ }^{14}$ Apparently, the loop region provides more flexibility for Cys to adopt a variety of orientations as opposed to the rigidity of a helical scaffold. This comparison shows that secondary and tertiary protein structure serves as a significant determinant for specific recognition of metals to thiolate rich sites. It is reasonable to expect that metal affinity and selectivity in $3 \mathrm{SCC}$ s will be affected by these structural factors as $\mathrm{Zn}(\mathrm{II})$ and $\mathrm{Hg}(\mathrm{II})$ binding requires more reorganization energy than $\mathrm{Pb}$ (II) or $\mathrm{As}$ (III) binding. Furthermore, these factors may contribute to metal differentiation between natural proteins when comparing similar first coordination sphere ligands in dramatically different protein folds.

While we have described the importance of preorganization of metal binding to a $\mathrm{Cys}_{3}$ site, the concept can be more generally applied to any ion binding to this type of protein. Hartmann et al. have shown that anions bind to coiled coils of trimeric autotransporter adhesions with the most frequent residues to recognize these anions being arginine (Arg) located in $d$ layers. ${ }^{60}$ Comparison of apo and anion-containing structures of $\operatorname{Arg}_{3}$ sites in coiled coil proteins demonstrated that the Arg side chains are preorganized for anion binding. While the examples with metal-Cys bonds correspond to directional coordinative covalent interactions, the examples of the adhesion proteins correspond to distance, but not orientation, dependent. Nonetheless, the same concept of minimizing reorganization energy of the side chains upon ion binding appears to be operative. 


\section{Effect of Metal Binding on the Hydrophobic Layers Forming the Second Coordination Sphere}

Because the Cys ligands are predisposed, but not preorganized, the 16Cys plane of the $\mathrm{Hg}(\mathrm{III})_{\mathrm{S}} \mathrm{Zn}(\mathrm{II})_{\mathrm{N}}(\mathrm{GRAND}-\mathrm{CSL} 16 \mathrm{CL} 30 \mathrm{H})_{3}{ }^{+}$structure is shifted toward the C-termini by $\sim 1.30 \AA$ as compared to the Cys plane in apo-(CSL16C) $)_{3}$ (Figure 1). This Cys rearrangement affects the hydrophobic cavities around the metal site. Whereas the shift decreases the interlayer spacing between the 16Cys and 19Leu layers, the opposite effect is observed above the metal site between 16Cys and 12Leu layers. This region is enlarged sufficiently to accommodate a noncoordinating water molecule $2.79 \AA$ above the $\mathrm{Hg}$ (II) atom (with respect to the $\mathrm{N}$-termini) (Figure $\mathrm{S} 8$ ). $\mathrm{Hg}(\mathrm{II})$ is trigonal planar with a $\mathrm{S}-\mathrm{Hg}(\mathrm{II})-\mathrm{S}$ angle close to a perfect $120^{\circ}$ and the $\mathrm{Hg}$ (II) ion is not distorted out of the Cys plane toward the water. Thus, the possibility of a pseudo tetrahedral $\mathrm{Hg}(\mathrm{II}) \mathrm{S}_{3} \mathrm{O}$ structure is eliminated. This water, on the other hand, forms hydrogen bonds with the p-orbitals of Cys sulfur atoms (O-S distance of $3.88 \AA$ ), stabilizing the overall charge of the metal site. In addition, steric clashing between the 12Leu residues and water was not observed (validated by MolProbity ${ }^{61}$ ). However, in the metalated trigonal pyramidal cases where the thiols are preorganized prior to metal binding, water is not observed between either of the interspace layers around the metal site (Figure S8), indicating that when the thiol ligands remain unchanged from the apo-coordination (helical core- and N-termini-directed), less space is generated between the 12Leu and bound-16Cys layers. At the same time, the resulting endocoordination mode for metal binding below the sulfur plane removes any vacant space below the metal site.

The cysteine rotamer conformations for trigonal pyramidal complexes are unaffected by the size of the metal. Instead, it is the hydrophobic packing in the second coordination sphere where the metal size influences structure. The larger the size of the metal, the farther the ion's displacement from the sulfur plane, and, consequently, the stereochemically active lone pair will have a greater impact on side-chain packing at the Leu layer below the metal site. Thus, to avoid steric clashes between the metal and adjacent layers, the Leu residues below the $\mathrm{Cys}_{3}$ plane have to reorient slightly toward the helical interface and rotate down toward the C-termini in the metalated structures as compared to apo-(CSL16C) ${ }_{3}$ (Figure S10). This perturbation is larger for $\mathrm{Pb}(\mathrm{II})$ complexation than for the smaller $\mathrm{As}(\mathrm{III})$ ion. The endoisomer requires the Leu residues below the metal plane to shift to accommodate the metal lone pairs. One should remember at this point that the peptide sequence from the $d$ position to the a (metal plane) has three intervening residues, whereas there are only two residues upon going from $a$ (metal plane) to $d$. The metalloids that require trigonal pyramidal geometry, regardless of size or charge, lie within the region with less space between layers so as to minimize cysteine side-chain rotation (i.e., accepting preorganized binding), instead forcing the adjacent hydrophobic layer conformation to change.

Given these observations, one might then ask why the 4-coordinate $\mathrm{Zn}$ (II) ion does not accept the preorganized cysteine conformation, but rather accepts the significantly perturbed cysteine rotamers observed for the trigonal planar $\mathrm{Hg}(\mathrm{II})$ structures? One model might suggest that with respect to metal sulfur bonding, trigonal pyramidal versus pseudo tetrahedral polyhedral geometries would be closely similar. Instead, we see they are 
markedly different and hypothesize that this is a consequence of the bound water, which appears to have a more significant impact on the structure than a lone pair.

We compared the pseudo tetrahedral and trigonal pyramidal geometries in these designed peptides by overlaying the $\mathrm{Zn}(\mathrm{II}) \mathrm{S}_{3} \mathrm{O}$ and $\mathrm{As}(\mathrm{III}) \mathrm{S}_{3}$ environments (Figure 6). Both metal sites share the same first coordination sphere ( $\mathrm{Cys}_{3}$ ligand set), and both ions have comparable radii (As(III), $0.72 \AA$ and $\mathrm{Zn}(\mathrm{II}), 0.74 \AA$ 跨 ${ }^{50}$ However, the As(III) ion accepts the preorganized thiol orientation $\left(\chi 1=-59.66^{\circ}\right)$ resulting in a sulfur plane similar to the apostructure, while $\mathrm{Zn}$ (II) binding induces reorientation of the thiols outward to the helical interface $\left(\chi 1=-149.39^{\circ}\right)$, lowering the Cys plane by $\sim 1.30 \AA$ from its location in the unmetalated and As(III) structures. Intriguingly, even though the sulfur planes are shifted between these two geometries, the alignment of the two structures indicates that the absolute positions of bound $\mathrm{As}(\mathrm{III})$ and $\mathrm{Zn}(\mathrm{II})$ are relatively close, with As(III) slightly shifted toward the $\mathrm{N}$-termini. This observation implies that the Cys rotation required for the $\mathrm{Zn}(\mathrm{II}) \mathrm{S}_{3} \mathrm{O}$ site allows the $\mathrm{Zn}$ (II) ion to fit in the same position as the As(III) ion despite the very different cysteine rotamer angles and three sulfur plane positions. Moreover, $\mathrm{Zn}(\mathrm{II}) \mathrm{S}_{3} \mathrm{O}$ has a longer $\mathrm{S} \gamma-\mathrm{S} \gamma$ separation $(3.92 \AA$ ) as compared to the As(III) site (3.25 $\AA$ ) because Zn(II) sits just $0.20 \AA$ above the sulfur plane, while As(III) is bound with an endo-conformation that allows the metal to sit $1.30 \AA$ below the metal plane.

To understand these observations further, we must consider the differences in packing at the 19Leu position and how these hydrophobic residues can accommodate a stereochemically active lone pair versus a coordinated solvent. The packing of the hydrophobic layer below the metal site is similar between $\mathrm{Zn}(\mathrm{II}) \mathrm{S}_{3} \mathrm{O}$ and $\mathrm{As}(\mathrm{III}) \mathrm{S}_{3}$ sites in $\mathrm{As}(\mathrm{III})(\mathrm{CSL} 9 \mathrm{C})_{3}$ and $\mathrm{Zn}(\mathrm{II})\left(\mathrm{H}_{2} \mathrm{O}\right)$ (GRAND-CSL12A16C) ${ }_{3}{ }^{-}$(Figure 6c). The fact that $\mathrm{Zn}(\mathrm{II})$ and As(III) have nearly identical sizes and are located at essentially the same position in the coiled coil may explain this similarity. The most important factor is that the 19Leu layer comes closer to the three atom sulfur plane in the $\mathrm{Zn}(\mathrm{II}) \mathrm{S}_{3} \mathrm{O}$ site by $\sim 1.30 \AA$ A. Given the small $\mathrm{Zn}$ (II) to 19Leu separation, there is insufficient space toward the 19Leu layer for a solvent molecule within $2.18 \AA$ of $\mathrm{Zn}$ (II). This is consistent with the observation that we have never observed a solvent atom below the $\mathrm{Cys}_{3}$ plane when Leu is in the 19th position. Therefore, there are two possibilities for the formation of a pseudo tetrahedral center. The first, that $\mathrm{Zn}$ (II) adopts the same cysteine rotamers as the $\mathrm{Pb}$ (II) or As(III) ions, is unlikely because it would require that the bound water point toward the C-termini where there is not enough space to accommodate solvent in the resultant cavity. The second possibility is that which is observed. The cysteines rotate as in the $\mathrm{Hg}$ (II) structure to allow water to occupy the fourth coordination site in the cavity toward the N-termini. A similar phenomenon is expected for $\mathrm{Cd}(\mathrm{II})$, which is larger than $\mathrm{Zn}$ (II) and has a Cd(II)-O distance of $2.32 \AA$ based on EXAFS studies. ${ }^{52}$ For these reasons, we conclude that the apo-Cys 3 site in the 3SCC CS and GRAND-CS series is predisposed, but not preorganized for the sequestration of pseudo tetrahedral polyhedra, regardless of the metal.

Human retrotransposons are responsible for up to $17 \%$ of variability in the human genome. ${ }^{62}$ These proteins form highly conserved $\mathrm{N}$-terminal trimeric coiled coil domains that connect to a central RNA Recognition motif that selects for the binding of singlestranded nucleic acids. Cysteine residues are located in two different a layers of the human 
Line1 ORF1 protein ${ }^{63}$ as shown in Figure S1, making this a potential heavy metal binding site similar to those described for the GRAND-CS peptides. In vivo assays of retrotransposon function demonstrated significant sensitivity to mutations that lead either to mis-assembly or to excessive rigidity of the coiled coil. ${ }^{15}$ In particular, it was suggested that the kinetics for unwinding the target RNA sequence are highly dependent on the flexibility of the trimeric segment. Heavy metal binding to the Line 1 ORF $1 \mathrm{p}$ is expected to cause a much more rigid 3SCC due to the enthalpically strong $\mathrm{M}-\mathrm{S}$ bonds. In such a case, the retrotransposon is not expected to function properly. Thus, one can imagine that the binding of lead, arsenic, or mercury could cause significant perturbation to the genetic machinery of a cell, potentially generating long-term mutagenic effects.

\section{CONCLUSION}

We have provided the first systematic crystallographic study for the extent of preorganization versus predisposition of metal bound environments in designed proteins. The extent of ligand rotameric changes for $\mathrm{Cys}_{3}$ ligands upon binding metals is not dependent on size or charge. Instead, the preferred coordination geometry of the metal defines the allowed rotamers. For trigonal planar structures, significant rotation of the Cys ligands is required to accommodate any metal. In contrast, the cysteine environment is preorganized for trigonal pyramidal ions when they adopt an endo conformation placed toward the C-termini of the coiled coil. Four-coordinate, pseudo tetrahedral structures are not preorganized and require significant cysteine repositioning, likely due to the energy penalty required to fit a solvent water molecule below the sulfur plane. Thus, both metal and protein structural preferences define the geometry and positioning of the ligands and metals in these assemblies. It should be emphasized that this study explicitly examined metal binding to a site cysteine residues and that different rules for preorganization versus predisposition may exist when the cysteines are incorporated into a $d$ layer as previous structural studies have shown that these sites have markedly different preferred cysteine side-chain conformations in the apo-peptides. ${ }^{46}$

While these studies have greatly clarified the factors that lead to metal ion site selectivity in designed proteins, the insight garnered herein is also important for understanding heavy metal recognition in native metalloregulatory proteins and human retrotransposons. Given the ideal $\mathrm{Pb}$ (II) and $\mathrm{As}(\mathrm{III})$ geometries revealed by these studies, the trimeric coiled coil in human Line 1 transposons is expected to show high affinity for heavy metals at tris cysteine sites found at a sites of heptads VI and VII. As the flexibility of this domain is essential for proper functioning, one can conceive of a new mechanism for the perturbation of genetic information through heavy metal exposure to these proteins at very low concentrations. At the same time, while we see that helical bundles provide a template offering selectivity for distinguishing different metals, these structures do not easily allow for conformational changes necessary to induce metalloregulatory switches. We conclude that greater metal ion selectivity can be achieved with preorganized helical assemblies, but that metalloregulatory proteins such as MerR may sacrifice, to some degree, metal recognition to optimize function. Thus, more promiscuous metal sites located in loop regions would be tolerated to allow for large protein conformational changes that are necessary for function. 


\section{MATERIALS AND METHODS}

\section{Peptide Synthesis and Purification}

Peptides were synthesized on an Applied Biosystems 433A peptide synthesizer, purified, and characterized as previously reported. ${ }^{64}$ Concentration of peptide stock solutions was determined by quantitation of the cysteine thiols using Ellman's test, which uses dithionitrobenzoate (DTNB) as an indicator. ${ }^{65}$

\section{Crystallizations}

All peptides were crystallized by sitting drop vapor diffusion experiments at $20^{\circ} \mathrm{C}$ with drops containing equal volumes of peptide $(0.75 \mu \mathrm{L})$ and precipitant $(0.75 \mu \mathrm{L})$ solutions. Apo-(CSL16C) $)_{3}$ crystals were prepared from $20 \mathrm{mg} / \mathrm{mL}$ CSL16C, $15 \mathrm{mM} \mathrm{Zn}(\mathrm{OAc})_{2}$, and 5 $\mathrm{mM}$ Tris buffer $\mathrm{pH} 8.5$ with a precipitant solution (40\% (v/v) PEG-400 and sodium acetate buffer $\mathrm{pH} 4.5$ with a final well solution $\mathrm{pH}$ of 5.4$)$. $\mathrm{Hg}(\mathrm{II})_{\mathrm{S}} \mathrm{Zn}(\mathrm{II})_{\mathrm{N}}(\mathrm{GRAND}-$ CSL16CL30H) ${ }_{3}{ }^{+}$was prepared from $20 \mathrm{mg} / \mathrm{mL}$ GRAND-CSL16CL30H peptide, 0.92 equiv of $\mathrm{HgCl}_{2}$ per $3 \mathrm{SCC}$ peptide, $\left.15 \mathrm{mM} \mathrm{Zn(OAc}\right)_{2}$, and $5 \mathrm{mM}$ Tris buffer $\mathrm{pH}$ 8.5. The well solution contained 15\% (v/v) PEG-2000 MME and 0.1 M MES buffer pH 6.5. $\mathrm{Zn}(\mathrm{II})\left(\mathrm{H}_{2} \mathrm{O}\right)$ (GRAND-CSL12A16C) ${ }_{3}{ }^{-}$crystals were grown from a peptide solution containing 20 $\mathrm{mg} / \mathrm{mL}$ GRAND-CSL12A16C peptide, $15 \mathrm{mM} \mathrm{Zn(OAc})_{2}$, and $5 \mathrm{mM}$ Tris buffer $\mathrm{pH} 8.5$ and a precipitant solution (0.1 M HEPES pH 7.5 and 40\% (v/v) 1,2-propanediol). Last, a $\mathrm{Pb}(\mathrm{II})_{\mathrm{S}} \mathrm{Zn}(\mathrm{II})_{\mathrm{N}}(\mathrm{GRAND}-\mathrm{CSL} 16 \mathrm{CL} 30 \mathrm{H})_{3}{ }^{+}$solution was prepared from $20 \mathrm{mg} / \mathrm{mL}$ GRANDCSL16CL30H peptide, 1.0 equiv of $\mathrm{Pb}\left(\mathrm{NO}_{3}\right)_{2}$ per $3 \mathrm{SCC}$ peptide, $15 \mathrm{mM} \mathrm{Zn}(\mathrm{OAc})_{2}$, and 5 $\mathrm{mM}$ Tris buffer $\mathrm{pH}$ 8.5. The well solution contained 0.1 M MES pH 6.5 and 25\% (w/v) PEG-1000. Crystals were cryoprotected in mother liquor containing $20 \%$ glycerol prior to supercooling in liquid $\mathrm{N}_{2}$ for data collection.

\section{Data Collections and Refinements}

Data were collected at the Advanced Photon Source of the Argonne National Laboratory on the LS-CAT Beamlines 21-ID-F and 21-ID-G, equipped with Mar 225 CCD and Mar 300 CCD detectors, respectively. All data were collected with a $1^{\circ}$ oscillation, and then processed and scaled with HKL2000. ${ }^{66}$ All structures were solved by molecular replacement using Molrep ${ }^{67}$ in the CCP4 suite of programs, ${ }^{68-70}$ and then underwent iterative rounds of electron density fitting and refining in $\operatorname{Coot}^{71}$ and Buster 2.11.2 program, ${ }^{72}$ respectively, unless otherwise noted. The crystallographic data collection and refinement statistics of the crystal structures are noted in Tables S1 and S2. Apo-(CSL16C) $)_{3}$ crystallized in the space group $\mathrm{C} 2$, containing one three-stranded coiled coil per asymmetric unit (ASU) with a Matthew's coefficient of 2.21 corresponding to $44.50 \%$ solvent content. The structure was solved using the published apo-(CSL9C) 3 structure (PDB code: $3 \mathrm{LJM})^{46}$ as a search model in Molrep in which 9Cys and 16Leu of the search model were mutated to Leu and Cys, respectively. The solution was refined to $1.42 \AA\left(R_{\text {working }}=19.60 \%, R_{\text {free }}=23.00 \%\right)$. The validity of the models was verified using the MolProbity software. ${ }^{61}$ All residues are present within allowed regions of the Ramachandran plot.

The peptides in the GRAND-CoilSer series crystallized in the $R 32$ space group. The Matthews' coefficient estimates one helix of the GRAND-CoilSer peptide per ASU. The 
combination of three adjacent ASUs constrained by a 3-fold axis results in a well-folded parallel 3SCC structure. The $\mathrm{Hg}(\mathrm{II})_{\mathrm{S}} \mathrm{Zn}(\mathrm{II})_{\mathrm{N}}(\mathrm{GRAND}-\mathrm{CSL} 16 \mathrm{CL} 30 \mathrm{H})_{3}{ }^{+}$structure has a Matthews' coefficient (2.41) consistent with $49.05 \%$ solvent content per ASU and was solved using the five heptads of GRAND-CSL12 ${ }_{\mathrm{D}} \mathrm{L} 16 \mathrm{C}$ as a search model. The side chains of the model were included with the D-Leu residue at the twelfth position mutated to LLeu. ${ }^{73}$ Electron difference density maps $\left(F_{\mathrm{o}}-F_{\mathrm{c}}\right)$ contoured at $3 \sigma$ show two possible metal sites at the 16th (16Cys) and the 30th (30His) positions corresponding to $\mathrm{Hg}$ (II) and $\mathrm{Zn}$ (II) ions, respectively. These positions were confirmed by solving the structure by single anomalous dispersion using AutoSol in Phenix..$^{70,74-76} \mathrm{The} \mathrm{Hg}(\mathrm{II})_{\mathrm{S}} \mathrm{Zn}(\mathrm{II})_{\mathrm{N}}(\mathrm{GRAND}-$ $\mathrm{CSL} 16 \mathrm{CL} 30 \mathrm{H})_{3}{ }^{+}$structure was refined to $2.09 \AA\left(R_{\text {working }}=21.80 \%, R_{\text {free }}=25.70 \%\right)$. The single strand in the ASU of $\mathrm{Zn}(\mathrm{II})\left(\mathrm{H}_{2} \mathrm{O}\right)$ (GRAND-CSL12A16C) ${ }_{3}{ }^{-}$was solved using GRAND-CSL12 ${ }_{\mathrm{D}}$ L16C as a search model in Molrep. The top result was then used as a starting model in AutoBuild Wizard software (Phenix) ${ }^{77-80}$ to estimate iteratively experimental crystallographic phases and improve the model-based map correlations. During the cycles, the existing model was chopped into pieces and then was rebuilt from the remaining ends based on statistical density distributions. These processes were repeated several times until overlapping segments covered the entire model. After that, the AutoBuild-solved solution was refined. The solvent content per ASU of this structure is 48.09\% (Matthew's coefficient of 2.37). The structure was refined to $1.89 \AA$ ( $R_{\text {working }}=$ $\left.20.60 \%, R_{\text {free }}=22.40 \%\right)$. The $\mathrm{Pb}(\mathrm{II})_{\mathrm{S}} \mathrm{Zn}(\mathrm{III})_{\mathrm{N}}(\mathrm{GRAND}-\mathrm{CSL} 16 \mathrm{CL} 30 \mathrm{H})_{3}{ }^{+}$structure was solved using a single helix of $\mathrm{Hg}(\mathrm{II})_{\mathrm{S}} \mathrm{Zn}(\mathrm{III})_{\mathrm{N}}(\mathrm{GRAND}-\mathrm{CSL} 16 \mathrm{CL} 30 \mathrm{H})_{3}{ }^{+}$as a search model in Molrep. The Matthew's coefficient is 2.47 corresponding to $50.24 \%$ solvent per ASU. The structure was refined to $2.13 \AA\left(R_{\text {working }}=20.80 \%, R_{\text {free }}=23.70 \%\right)$.

Protein Data Bank (PDB): 5K92, apo-(CSL16C) $)_{3} ; 5 \mathrm{~KB} 0, \mathrm{~Pb}-(\mathrm{III})_{\mathrm{S}} \mathrm{Zn}(\mathrm{II})_{\mathrm{N}}(\mathrm{GRAND}-$ CSL16CL30H $)_{3}{ }^{+} ; 5 \mathrm{~KB} 1, \mathrm{Hg}(\mathrm{II})_{\mathrm{S}} \mathrm{Zn}-(\mathrm{II})_{\mathrm{N}}(\mathrm{GRAND}-\mathrm{CSL} 16 \mathrm{CL} 30 \mathrm{H})_{3}{ }^{+} ; 5 \mathrm{~KB} 2, \mathrm{Zn}(\mathrm{II})\left(\mathrm{H}_{2} \mathrm{O}\right)$ $\left(\right.$ GRAND-CSL12A16C) ${ }_{3}{ }^{-}$.

\section{Supplementary Material}

Refer to Web version on PubMed Central for supplementary material.

\section{Acknowledgments}

V.L.P., L.R., and M.L.Z. thank the National Institutes of Health for support of this research (ES012236), and J.A.S. is supported by the University of Michigan Center for Structural Biology. L.R. thanks Dr. Jennifer Meagher, David Smith, and Zdzislaw Wawrzak for data collections. Use of the Advanced Photon Source, an Office of Science User Facility operated for the U.S. Department of Energy (DOE) Office of Science by Argonne National Laboratory, was supported by the U.S. DOE under contract no. DE-AC02-06CH11357. Use of the LS-CAT Sector 21 was supported by the Michigan Economic Development Corporation and the Michigan Technology Tri-Corridor (Grant 085P1000817).

\section{References}

1. Helmann JD, Ballard BT, Walsh CT. Science. 1990; 247(4945):946-948. [PubMed: 2305262]

2. Brown NL, Stoyanov JV, Kidd SP, Hobman JL. FEMS Microbiol Rev. 2003; 27(2-3):145-163. [PubMed: 12829265]

3. Busenlehner LS, Pennella MA, Giedroc DP. FEMS Microbiol Rev. 2003; 27(2-3):131-143. [PubMed: 12829264] 
4. Hobman JL, Julian DJ, Brown NL. BMC Microbiol. 2012; 12(1):1-12. [PubMed: 22221383]

5. Chen PR, Wasinger EC, Zhao J, van der Lelie D, Chen LX, He C. J Am Chem Soc. 2007; 129(41): 12350-12351. [PubMed: 17880216]

6. Utschig LM, Bryson JW, O’Halloran TV. Science. 1995; 268(5209):380-385. [PubMed: 7716541]

7. Shewchuk LM, Verdine GL, Walsh CT. Biochemistry. 1989; 28:2331-2339. [PubMed: 2719955]

8. Ralston DM, O’Halloran TV. Proc Natl Acad Sci U S A. 1990; 87(10):3846-3850. [PubMed: 2187194]

9. Watton SP, Wright JG, MacDonnell FM, Bryson JW, Sabat M, O’Halloran TV. J Am Chem Soc. 1990; 112:2824-2826.

10. Wright JG, Tsang H, Penner-Hahn JE, O'Halloran TV. J Am Chem Soc. 1990; 112(16):24342435.

11. Penner-Hahn JE, Tsang HT, O’Halloran TV, Wright J. Phys B. 1989; 158:117-118.

12. Warren MJ, Cooper JB, Wood SP, Shoolingin-Jordan PM. Trends Biochem Sci. 1998; 23(6):217221. [PubMed: 9644976]

13. Magyar JS, Weng T-C, Stern CM, Dye DF, Rous BW, Payne JC, Bridgewater BM, Mijovilovich A, Parkin G, Zaleski JM, Penner-Hahn JE, Godwin HA. J Am Chem Soc. 2005; 127(26):9495-9505. [PubMed: 15984876]

14. Erskine PT, Duke EMH, Tickle IJ, Senior NM, Cooper JB. Acta Crystallogr, Sect D: Biol Crystallogr. 2000; 56:421-430. [PubMed: 10739915]

15. Khazina E, Truffault V, Büttner R, Schmidt S, Coles M, Weichenrieder O. Nat Struct Mol Biol. 2011; 18(9):1006-1014. [PubMed: 21822284]

16. Khazina E, Weichenrieder O. Proc Natl Acad Sci U S A. 2009; 106(3):731-736. [PubMed: 19139409]

17. Yu F, Cangelosi VM, Zastrow ML, Tegoni M, Plegaria JS, Tebo AG, Mocny CS, Ruckthong L, Qayyum H, Pecoraro VL. Chem Rev. 2014; 114(7):3495-3578. [PubMed: 24661096]

18. Peacock AFA, Iranzo O, Pecoraro VL. Dalton Trans. 2009; 13:2271-2280.

19. DeGrado WF, Summa CM, Pavone V, Nastri F, Lombardi A. Annu Rev Biochem. 1999; 68:779_ 819. [PubMed: 10872466]

20. Kohn WD, Hodges RS. Trends Biotechnol. 1998; 16:379-389.

21. Baltzer L, Nilsson H, Nilsson J. Chem Rev. 2001; 101(10):3153-3163. [PubMed: 11710066]

22. Lovejoy B, Choe S, Cascio D, Mcrorie DK, William F, Eisenberg D, Degrado WF. Science. 1993; 259(5099):1288-1293. [PubMed: 8446897]

23. Ogihara MS, Weiss WF, DeGrado DE. Protein Sci. 1997; 6:80-88. [PubMed: 9007979]

24. Dieckmann, G.; Heilman, S.; DeGrado, W.; Pecoraro, VL. De Novo Design of Metallopeptides. In: Kessissoglou, DP.; Coucouvanis, D.; Kanatzidas, M., editors. An Inorganic Perspective of Life. Elsevier; Amsterdam: 1995. p. 275

25. Dieckmann GR, McRorie DK, Lear JD, Sharp KA, DeGrado WF, Pecoraro VL. J Mol Biol. 1998; 280(5):897-912. [PubMed: 9671558]

26. Dieckmann GR, Mcrorie DK, Tierney DL, Utschig LM, Singer CP, O'Halloran TV, Penner-Hahn JE, Degrado WF, Pecoraro VL. J Am Chem Soc. 1997; 119(4):6195-6196.

27. Matzapetakis M, Farrer BT, Weng T-C, Hemmingsen L, Penner-Hahn JE, Pecoraro VL. J Am Chem Soc. 2002; 124(27):8042-8054. [PubMed: 12095348]

28. Matzapetakis M, Pecoraro VL. J Am Chem Soc. 2005; 127(51):18229-18233. [PubMed: 16366576]

29. Matzapetakis M, Ghosh D, Weng T-C, Penner-Hahn JE, Pecoraro VL. JBIC, J Biol Inorg Chem. 2006; 11(7):876-890. [PubMed: 16855818]

30. Zampella G, Neupane KP, De Gioia L, Pecoraro VL. Chem - Eur J. 2012; 18(7):2040-2050. [PubMed: 22231489]

31. Zastrow ML, Peacock AFA, Stuckey JA, Pecoraro VL. Nat Chem. 2011; 4:118-123. [PubMed: 22270627]

32. Peacock AFA, Stuckey JA, Pecoraro VL. Angew Chem, Int Ed. 2009; 48(40):7371-7374. 
33. Peacock AFA, Hemmingsen L, Pecoraro VL. Proc Natl Acad Sci U S A. 2008; 105(43):1656616571. [PubMed: 18940928]

34. Iranzo O, Jakusch T, Lee K-H, Hemmingsen L, Pecoraro VL. Chem - Eur J. 2009; 15(15):37613772. [PubMed: 19229934]

35. Lee K-H, Cabello C, Hemmingsen L, Marsh ENG, Pecoraro VL. Angew Chem, Int Ed. 2006; 45(18):2864-2868.

36. Lee K-H, Matzapetakis M, Mitra S, Marsh ENG, Pecoraro VL. J Am Chem Soc. 2004; 126(30): 9178-9179. [PubMed: 15281796]

37. Babor M, Greenblatt HM, Edelman M, Sobolev V. Proteins: Struct, Funct, Genet. 2005; 59(2):221230. [PubMed: 15726624]

38. Gray HB, Malmström BG, Williams RJ. JBIC, J Biol Inorg Chem. 2000; 5(5):551-559. [PubMed: 11085645]

39. Hakansson K, Wehnert A, Liljas A. Acta Crystallogr, Sect D: Biol Crystallogr. 1994; 50:93-100. [PubMed: 15299481]

40. Hakansson K, Carlsson M, Svensson LA, Liljas A. J Mol Biol. 1992; 227(4):1192-1204. [PubMed: 1433293]

41. Maglio O, Nastri F, Pavone V, Lombardi A, DeGrado WF. Proc Natl Acad Sci U S A. 2003; 100(7):3772-3777. [PubMed: 12655072]

42. Ye J, Kandegedara A, Martin P, Rosen BP. J Bacteriol. 2005; 187(12):4214-4221. [PubMed: 15937183]

43. Eicken C, Pennella MA, Chen X, Koshlap KM, VanZile ML, Sacchettini JC, Giedroc DP. J Mol Biol. 2003; 333(4):683-695. [PubMed: 14568530]

44. Chang C-C, Lin L-Y, Zou X-W, Huang C-C, Chan N-L. Nucleic Acids Res. 2015; 43:7612-7623. [PubMed: 26150423]

45. Iranzo O, Ghosh D, Pecoraro VL. Inorg Chem. 2006; 45(25):9959-9973. [PubMed: 17140192]

46. Chakraborty S, Touw DS, Peacock AFA, Stuckey J, Pecoraro VL. J Am Chem Soc. 2010; 132(38): 13240-13250. [PubMed: 20825181]

47. The circular radius is calculated from the radius of the inner circle of the equatorial triangle that has each of the edges equal to C(alpha)-C(alpha) distance.

48. Gruff ES, Koch KS. J Am Chem Soc. 1990; 112:1245.

49. Santos RA, Gruff ES, Koch SA, Harbison GS. J Am Chem Soc. 1991; 113:469.

50. Mann, JB. Atomic Structure Calculations II Hartree-Fock Wavefunctions and Radial Expectation Values: Hydrogen to Lawrencium. Los Alamos Scientific Lab; Los Alamos, NM: 1968.

51. Cruickshank DWJ. Acta Crystallogr, Sect D: Biol Crystallogr. 1999; 55:583-601. [PubMed: 10089455]

52. Ruckthong, L. Ph D Dissertation. University of Michigan; Ann Arbor, MI: 2016. Crystallographic Comparison of Tris-thiolate Sites in Designed Proteins to Control Metal Geometries.

53. Shannon RD. Acta Crystallogr, Sect A: Cryst Phys, Diffr, Theor Gen Crystallogr. 1976; A32:751767.

54. Cremer D, Kraka E, Filatov M. ChemPhysChem. 2008; 9(17):2510-2521. [PubMed: 19012313]

55. An endo coordination mode occurs when both the $\beta$-carbon of Cys and the toxic ion are on the same side of the three atom sulfur plane, while an exo configuration occurs when the $\beta$-carbon of cysteine is on the opposite side from the metal position with respect to the three atom sulfur plane.

56. Christou G, Folting K, Huffman JC. Polyhedron. 1984; 3:1243-1247.

57. Rossini AJ, Macgregor AW, Smith AS, Schatte G, Schurko RW, Briand GG. Dalton Trans. 2013; 42(26):9533-9546. [PubMed: 23673540]

58. Touw DS, Nordman CE, Stuckey JA, Pecoraro VL. Proc Natl Acad Sci U S A. 2007; 104(29): 11969-11974. [PubMed: 17609383]

59. Erskine PT, Senior N, Awan S, Lambert R, Lewis G, Tickle IJ, Sarwar M, Spencer P, Thomas P, Warren MJ, Shoolingin-Jordan PM, Wood SP, Cooper JB. Nat Struct Biol. 1997; 4(12):10251031. [PubMed: 9406553] 
60. Hartmann MD, Ridderbusch O, Zeth K, Albrecht R, Testa O, Woolfson DN, Sauer G, DuninHorkawicz S, Lupas AN, Alvarez BH. Proc Natl Acad Sci U S A. 2009; 106(40):16950-16955. [PubMed: 19805097]

61. Chen VB, Arendall WB, Headd JJ, Keedy DA, Immormino RM, Kapral GJ, Murray LW, Richardson JS, Richardson DC. Acta Crystallogr, Sect D: Biol Crystallogr. 2010; 66(1):12-21. [PubMed: 20057044]

62. Lander ES, Linton LM, Birren B, Nusbaum C, Zody MC, Baldwin J, Devon K, Dewar K, Doyle M, FitzHugh W, Funke R, Gage D, Harris K, Heaford A, Howland J, Kann L, Lehoczky J, LeVine R, McEwan P, McKernan K, Meldrim J, Mesirov JP, Miranda C, Morris W, Naylor J, Raymond C, Rosetti M, Santos R, Sheridan A, Sougnez C, Stange-Thomann N, Stojanovic N, Subramanian A, Wyman D, Rogers J, Sulston J, Ainscough R, Beck S, Bentley D, Burton J, Clee C, Carter N, Coulson A, Deadman R, Deloukas P, Dunham A, Dunham I, Durbin R, French L, Grafham D, Gregory S, Hubbard T, Humphray S, Hunt A, Jones M, Lloyd C, McMurray A, Matthews L, Mercer S, Milne S, Mullikin JC, Mungall A, Plumb R, Ross M, Shownkeen R, Sims S, Waterston RH, Wilson RK, Hillier LW, McPherson JD, Marra MA, Mardis ER, Fulton LA, Chinwalla AT, Pepin KH, Gish WR, Chissoe SL, Wendl MC, Delehaunty KD, Miner TL, Delehaunty A, Kramer JB, Cook LL, Fulton RS, Johnson DL, Minx PJ, Clifton SW, Hawkins T, Branscomb E, Predki P, Richardson P, Wenning S, Slezak T, Doggett N, Cheng JF, Olsen A, Lucas S, Elkin C, Uberbacher E, Frazier M, Gibbs RA, Muzny DM, Scherer SE, Bouck JB, Sodergren EJ, Worley KC, Rives CM, Gorrell JH, Metzker ML, Naylor SL, Kucherlapati RS, Nelson DL, Weinstock GM, Sakaki Y, Fujiyama A, Hattori M, Yada T, Toyoda A, Itoh T, Kawagoe C, Watanabe H, Totoki Y, Taylor T, Weissenbach J, Heilig R, Saurin W, Artiguenave F, Brottier P, Bruls T, Pelletier E, Robert C, Wincker P, Smith DR, Doucette-Stamm L, Rubenfield M, Weinstock K, Lee HM, Dubois J, Rosenthal A, Platzer M, Nyakatura G, Taudien S, Rump A, Yang H, Yu J, Wang J, Huang G, Gu J, Hood L, Rowen L, Madan A, Qin S, Davis RW, Federspiel NA, Abola AP, Proctor MJ, Myers RM, Schmutz J, Dickson M, Grimwood J, Cox DR, Olson MV, Kaul R, Raymond C, Shimizu N, Kawasaki K, Minoshima S, Evans GA, Athanasiou M, Schultz R, Roe BA, Chen F, Pan H, Ramser J, Lehrach H, Reinhardt R, McCombie WR, de la Bastide M, Dedhia N, Blocker H, Hornischer K, Nordsiek G, Agarwala R, Aravind L, Bailey JA, Bateman A, Batzoglou S, Birney E, Bork P, Brown DG, Burge CB, Cerutti L, Chen HC, Church D, Clamp M, Copley RR, Doerks T, Eddy SR, Eichler EE, Furey TS, Galagan J, Gilbert JG, Harmon C, Hayashizaki Y, Haussler D, Hermjakob H, Hokamp K, Jang W, Johnson LS, Jones TA, Kasif S, Kaspryzk A, Kennedy S, Kent WJ, Kitts P, Koonin EV, Korf I, Kulp D, Lancet D, Lowe TM, McLysaght A, Mikkelsen T, Moran JV, Mulder N, Pollara VJ, Ponting CP, Schuler G, Schultz J, Slater G, Smit AF, Stupka E, Szustakowski J, Thierry-Mieg D, Thierry-Mieg J, Wagner L, Wallis J, Wheeler R, Williams A, Wolf YI, Wolfe KH, Yang SP, Yeh RF, Collins F, Guyer MS, Peterson J, Felsenfeld A, Wetterstrand KA, Patrinos A, Morgan MJ, de Jong P, Catanese JJ, Osoegawa K, Shizuya H, Choi S, Chen YJ. Nature. 2001; 409(6822):860-921. [PubMed: 11237011]

63. http://www.uniprot.org/uniprot/q9un81 (accessed Jun 1, 2016)

64. Farrer BT, Harris NP, Balchus KE, Pecoraro VL. Biochemistry. 2001; 40(48):14696-14705. [PubMed: 11724584]

65. Ellman GL. Arch Biochem Biophys. 1959; 82:70-77. [PubMed: 13650640]

66. Otwinowski Z, Minor W. Methods Enzymol. 1997; 276:307-326.

67. Vagin A, Teplyakov A. Acta Crystallogr, Sect D: Biol Crystallogr. 2010; 66:22-25. [PubMed: 20057045]

68. Winn MD, Ballard CC, Cowtan KD, Dodson EJ, Emsley P, Evans PR, Keegan RM, Krissinel EB, Leslie AGW, McCoy A, McNicholas SJ, Murshudov GN, Pannu NS, Potterton EA, Powell HR, Read RJ, Vagin A, Wilson KS. Acta Crystallogr, Sect D: Biol Crystallogr. 2011; 67(4):235-242. [PubMed: 21460441]

69. Potterton E, Briggs P, Turkenburg M, Dodson E. Acta Crystallogr, Sect D: Biol Crystallogr. 2003; 59(7):1131-1137. [PubMed: 12832755]

70. McCoy AJ, Grosse-Kunstleve RW, Adams PD, Winn MD, Storoni LC, Read RJ. J Appl Crystallogr. 2007; 40(4):658-674. [PubMed: 19461840]

71. Emsley P, Cowtan K. Acta Crystallogr, Sect D: Biol Crystallogr. 2004; 60:2126-2137. [PubMed: $15572765]$ 
72. Bricogne, G.; Blanc, E.; Brandl, M.; Flensburg, C.; Keller, P.; Paciorek, W.; Roversi, P.; Sharff, A.; Smart, OS.; Vonrhein, C.; Womack, TO. BUSTER version 2.11.2. Global Phasing Ltd.; Cambridge, UK:

73. Ruckthong L, Stuckey JA, Pecoraro VL. Methods Enzymol. 2016; doi: 10.1016/bs.mie. 2016.05.007

74. Terwilliger TC, Adams PD, Read RJ, McCoy AJ, Moriarty NW, Grosse-Kunstleve RW, Afonine PV, Zwart PH, Hung LW. Acta Crystallogr, Sect D: Biol Crystallogr. 2009; 65:582-601. [PubMed: 19465773]

75. Grosse-Kunstleve RW, Adams PD. Acta Crystallogr, Sect D: Biol Crystallogr. 2003; 59:19661673. [PubMed: 14573951]

76. Terwilliger TC. Acta Crystallogr, Sect D: Biol Crystallogr. 2000; 56:965-972. [PubMed: 10944333]

77. Terwilliger TC, Grosse-Kunstleve RW, Afonine PV, Moriarty NW, Zwart PH, Hung L-W, Read RJ, Adams PD. Acta Crystallogr, Sect D: Biol Crystallogr. 2008; 64:61-69. [PubMed: 18094468]

78. Terwilliger TC, Grosse-Kunstleve RW, Afonine PV, Moriarty NW, Adams PD, Read RJ, Zwart PH, Hung L-W. Acta Crystallogr, Sect D: Biol Crystallogr. 2008; 64:515-524. [PubMed: 18453687]

79. Terwilliger TC. Acta Crystallogr, Sect D: Biol Crystallogr. 2004; 60:2144-2149. [PubMed: 15572767]

80. Afonine PV, Grosse-Kunstleve RW, Echols N, Headd JJ, Moriarty NW, Mustyakimov M, Terwilliger TC, Urzhumtsev A, Zwart PH, Adams PD. Acta Crystallogr, Sect D: Biol Crystallogr. 2012; 68:352-367. [PubMed: 22505256] 

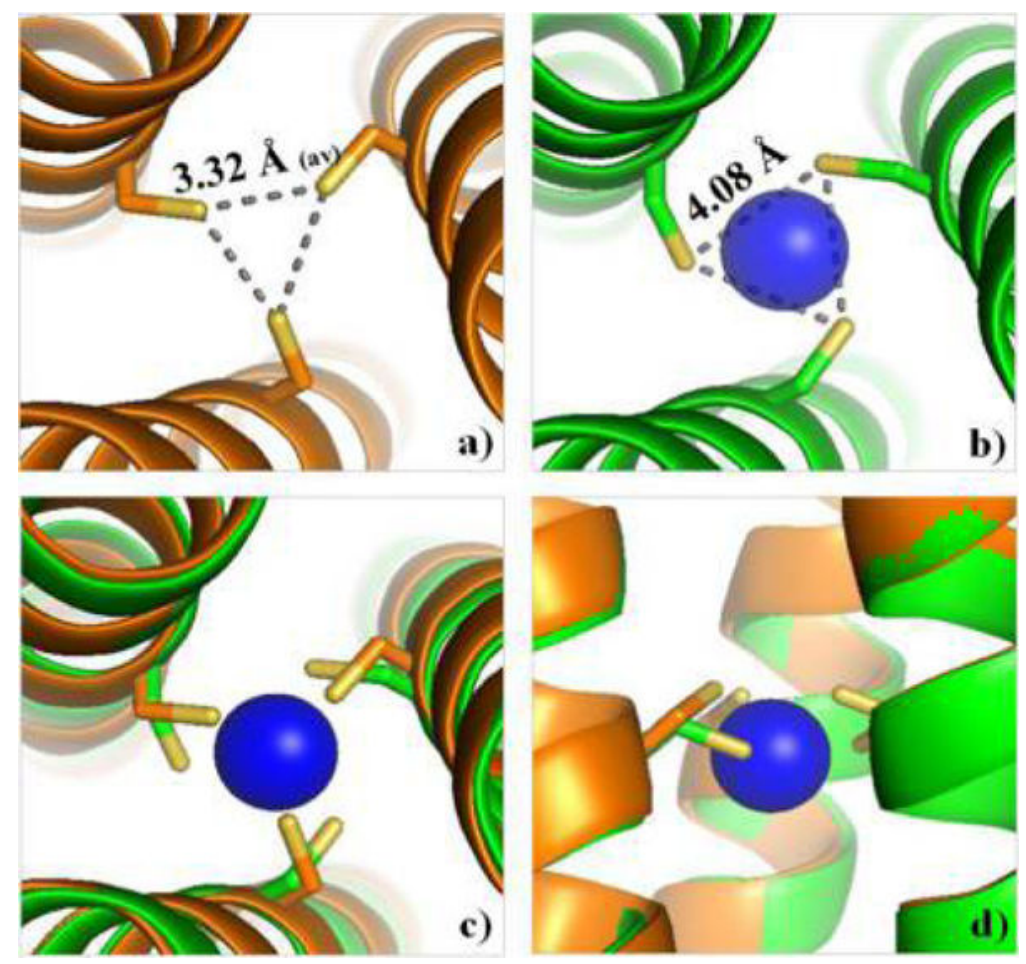

Figure 1.

Ribbon diagrams demonstrating an overlay of the cysteine-substituted 16th layer between $\mathrm{Hg}(\mathrm{III})_{\mathrm{S}} \mathrm{Zn}(\mathrm{II})_{\mathrm{N}}(\mathrm{GRAND}-\mathrm{CSL} 16 \mathrm{CL} 30 \mathrm{H})_{3}{ }^{+}$and apo-(CSL16C) ${ }_{3}$. Top-down (N-termini) view of the major conformer of Cys residues in (a) apo-(CSL16C) 3 and (b) $\mathrm{Hg}(\mathrm{III})_{\mathrm{S}} \mathrm{Zn}(\mathrm{II})_{\mathrm{N}}(\mathrm{GRAND}-\mathrm{CSL} 16 \mathrm{CL} 30 \mathrm{H})_{3}{ }^{+}$. (c) Top-down and (d) side-on views of the overlay showing the predisposition of three Cys ligands toward $\mathrm{Hg}$ (II) binding. Main-chain atoms of $\mathrm{Hg}(\mathrm{II})_{\mathrm{S}} \mathrm{Zn}-(\mathrm{III})_{\mathrm{N}}(\text { GRAND-CSL16CL30H })_{3}{ }^{+}$are colored in green and apo$(\mathrm{CSL16C})_{3}$ in orange. Cysteine side chains are shown as sticks with the sulfur atoms in yellow. $\mathrm{Hg}$ (II) is present as a blue sphere, and the water observed between the 12Leu and 16Cys cavity is omitted for clarity. 

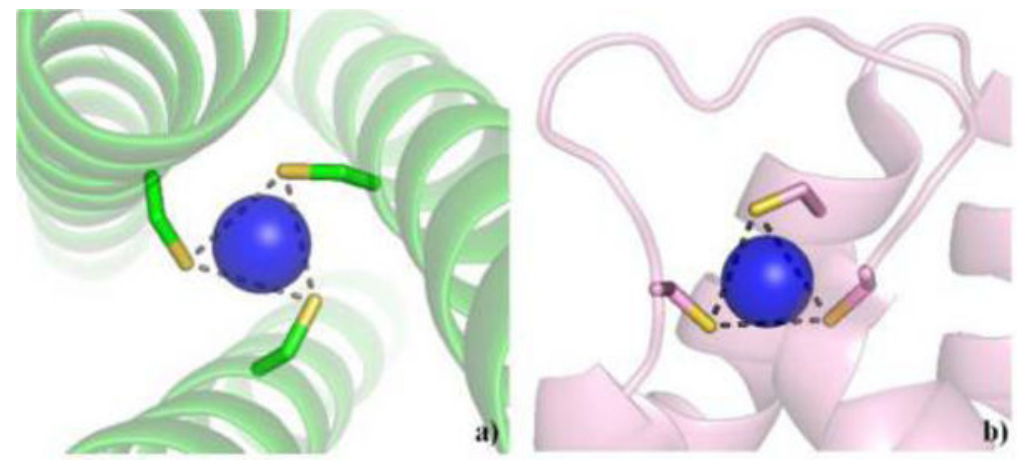

Figure 2.

Ribbon diagrams of the $\mathrm{Hg}(\mathrm{II}) \mathrm{S}_{3}$ sites in (a) $\mathrm{Hg}(\mathrm{II})_{\mathrm{S}} \mathrm{Zn}$-(II) $)_{\mathrm{N}}(\text { GRAND-CSL16CL30H })_{3}{ }^{+}$and (b) native MerR (PDB code: 4UA1). ${ }^{43}$ The Cys residues in both structures are shown as sticks with the sulfur atoms in yellow. The $\mathrm{Hg}$ (II) ions are shown as blue spheres. 

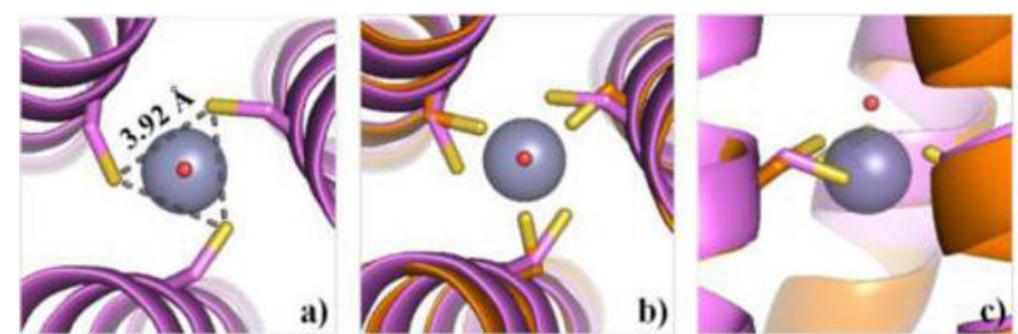

Figure 3.

Ribbon diagrams representing the predisposition of apo-Cys ligands toward a 4-coordinate $\mathrm{Zn}$ (II) $\mathrm{S}_{3} \mathrm{O}$ structure in the $3 \mathrm{SCC}$ environment. (a) Top-down view from the N-termini of the 4-coordinate binding site in $\mathrm{Zn}(\mathrm{II})\left(\mathrm{H}_{2} \mathrm{O}\right)(\mathrm{GRAND}-\mathrm{CSL} 12 \mathrm{AL} 16 \mathrm{C})_{3}{ }^{-}$.(b) Top-down and (c) side-on view of the overlay between the 4-coordinate $\mathrm{Zn}(\mathrm{II}) \mathrm{S}_{3} \mathrm{O}$ site and apo-(CSL16C) $)_{3}$. Main-chain atoms of $\mathrm{Zn}(\mathrm{II})\left(\mathrm{H}_{2} \mathrm{O}\right)(\mathrm{GRAND}-\mathrm{CSL} 12 \mathrm{AL} 16 \mathrm{C})_{3}{ }^{-}$and apo-(CSL16C) ${ }_{3}$ are shown as pink and orange ribbon diagrams, respectively. The 16Cys side chains are shown as sticks (sulfur = yellow). The $\mathrm{Zn}$ (II) ion and water are shown as gray and red spheres, respectively. 

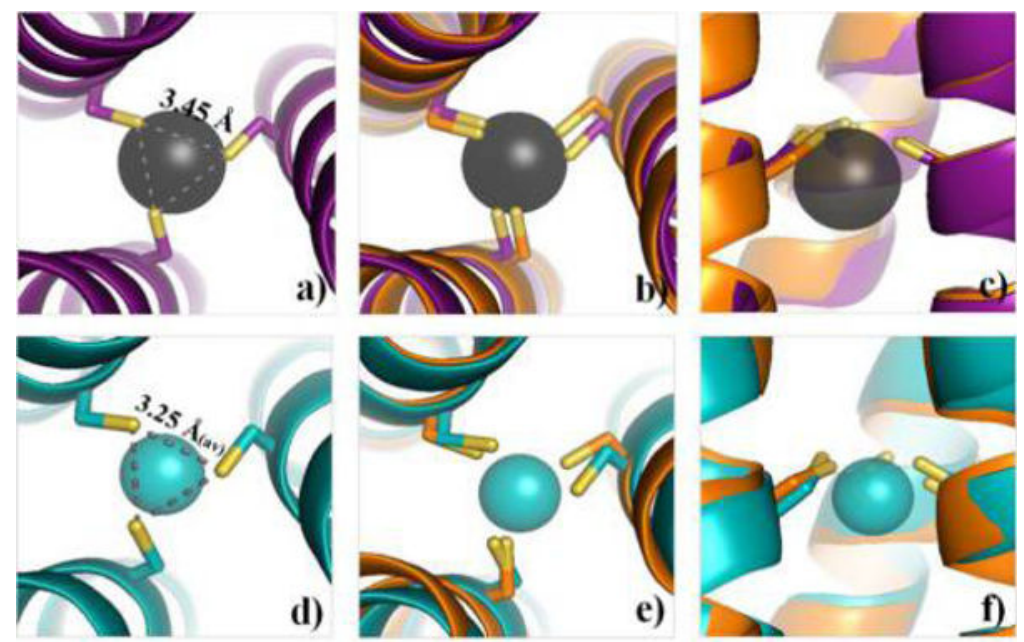

Figure 4.

Ribbon diagrams superimposing metalated $\mathrm{Pb}(\mathrm{II}) \mathrm{S}_{3}$ and $\mathrm{As}(\mathrm{III}) \mathrm{S}_{3}$ structures onto apo(CSL16C) ${ }_{3}$ demonstrate the preorganization of apo-Cys ligands to the trigonal pyramidal geometry. endo-Trigonal pyramidal structures of (a) $\mathrm{Pb}(\mathrm{II}) \mathrm{S}_{3}$ from $\mathrm{Pb}(\mathrm{II})_{\mathrm{S}} \mathrm{Zn}$ $(\mathrm{II})_{\mathrm{N}}(\mathrm{GRAND}-\mathrm{CSL} 16 \mathrm{CL} 30 \mathrm{H})_{3}{ }^{+}$and (d) As(III)S ${ }_{3}$ from As(III) (CSL9C) ${ }_{3}$ (PDB code: 2JGO). ${ }^{56}$ (b, e) Top-down and (c, f) side-on view of the overlay between metalated structure and apoprotein for $\mathrm{Pb}(\mathrm{II}) \mathrm{S}_{3}$ and $\mathrm{As}(\mathrm{III}) \mathrm{S}_{3}$, respectively. Main-chain atoms of $\mathrm{Pb}(\mathrm{II})_{\mathrm{S}} \mathrm{Zn}$ $\left({ }^{(I I)}\right)_{\mathrm{N}}\left(\text { GRAND-CSL16CL30H) }{ }_{3}{ }^{+}, \mathrm{As}(\mathrm{III})(\mathrm{CSL} 9 \mathrm{C})_{3} \text {, and apo-(CSL16C) }\right)_{3}$ are colored in purple, cyan, and orange, respectively (sulfur atoms = yellow). The $\mathrm{Pb}(\mathrm{II})$ and $\mathrm{As}(\mathrm{III})$ ions are shown as gray and cyan spheres, respectively. 

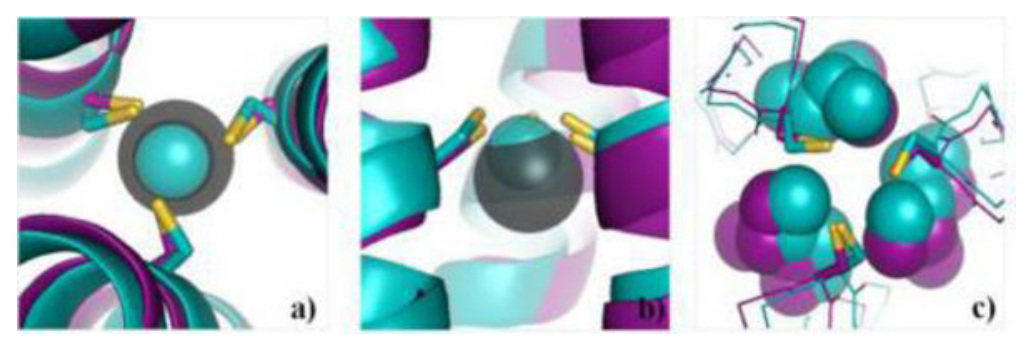

Figure 5.

Ribbon diagrams comparing trigonal pyramidal $\mathrm{Pb}(\mathrm{II}) \mathrm{S}_{3}$ and $\mathrm{As}(\mathrm{III}) \mathrm{S}_{3}$ (PDB code: $\left.2 \mathrm{JGO}\right)^{56}$ in an a site of the 3SCCs. (a) Top-down view from the N-termini and (b) side-on view of the overlaid binding sites. $\mathrm{Pb}(\mathrm{II})$ is situated at a distance of $1.63 \AA$ below the metal plane in $\mathrm{Pb}(\mathrm{II})_{\mathrm{S}} \mathrm{Zn}(\mathrm{II})_{\mathrm{N}}(\mathrm{GRAND}-\mathrm{CSL} 16 \mathrm{CL} 30 \mathrm{H})_{3}{ }^{+}$, while As(III) is at a distance $1.30 \AA$ below the metal plane in As(III)(CSL9C) 3 . (c) Packing of Leu layers below Cys sites (shown as spheres). Main-chain atoms of $\mathrm{Pb}(\mathrm{II})_{\mathrm{S}} \mathrm{Zn}(\mathrm{II})_{\mathrm{N}}(\mathrm{GRAND}-\mathrm{CSL} 16 \mathrm{CL} 30 \mathrm{H})_{3}{ }^{+}$are colored in purple and $\mathrm{As}(\mathrm{III})(\mathrm{CSL} 9 \mathrm{C})_{3}$ in cyan (sulfurs in yellow). The $\mathrm{Pb}(\mathrm{II})$ and $\mathrm{As}$ (III) ions are shown as gray and cyan spheres, respectively. 

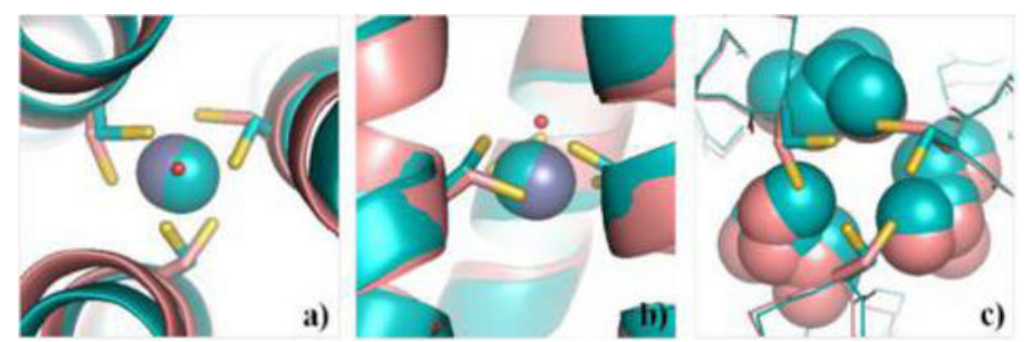

Figure 6.

Ribbon diagrams overlaying the $\mathrm{Zn}(\mathrm{II}) \mathrm{S}_{3} \mathrm{O}$ and $\mathrm{As}(\mathrm{III}) \mathrm{S}_{3}$ binding sites in $3 \mathrm{SCC}$ show that the positions of $\mathrm{As}$ (III) and $\mathrm{Zn}$ (II) are in close proximity, while the metalated Cys arrangements of the two geometries are completely different. (a) Top-down view from the $\mathrm{N}$-termini and (b) side-on view of the overlaid binding sites. (c) Top-down view from Ntermini, showing the Leu packing (spheres) below the Cys site (metal centers are omitted for clarity). The $\mathrm{Zn}(\mathrm{II})-\left(\mathrm{H}_{2} \mathrm{O}\right)(\mathrm{GRAND}-\mathrm{CSL} 12 \mathrm{AL} 16 \mathrm{C})_{3}{ }^{-}$is colored pink and As(III) (CSL9C) 3 is cyan (sulfurs = yellow). The $\mathrm{Zn}(\mathrm{II})$ and $\mathrm{As}(\mathrm{III})$ ions are shown as gray and cyan spheres, respectively. 


\section{을 \\ }

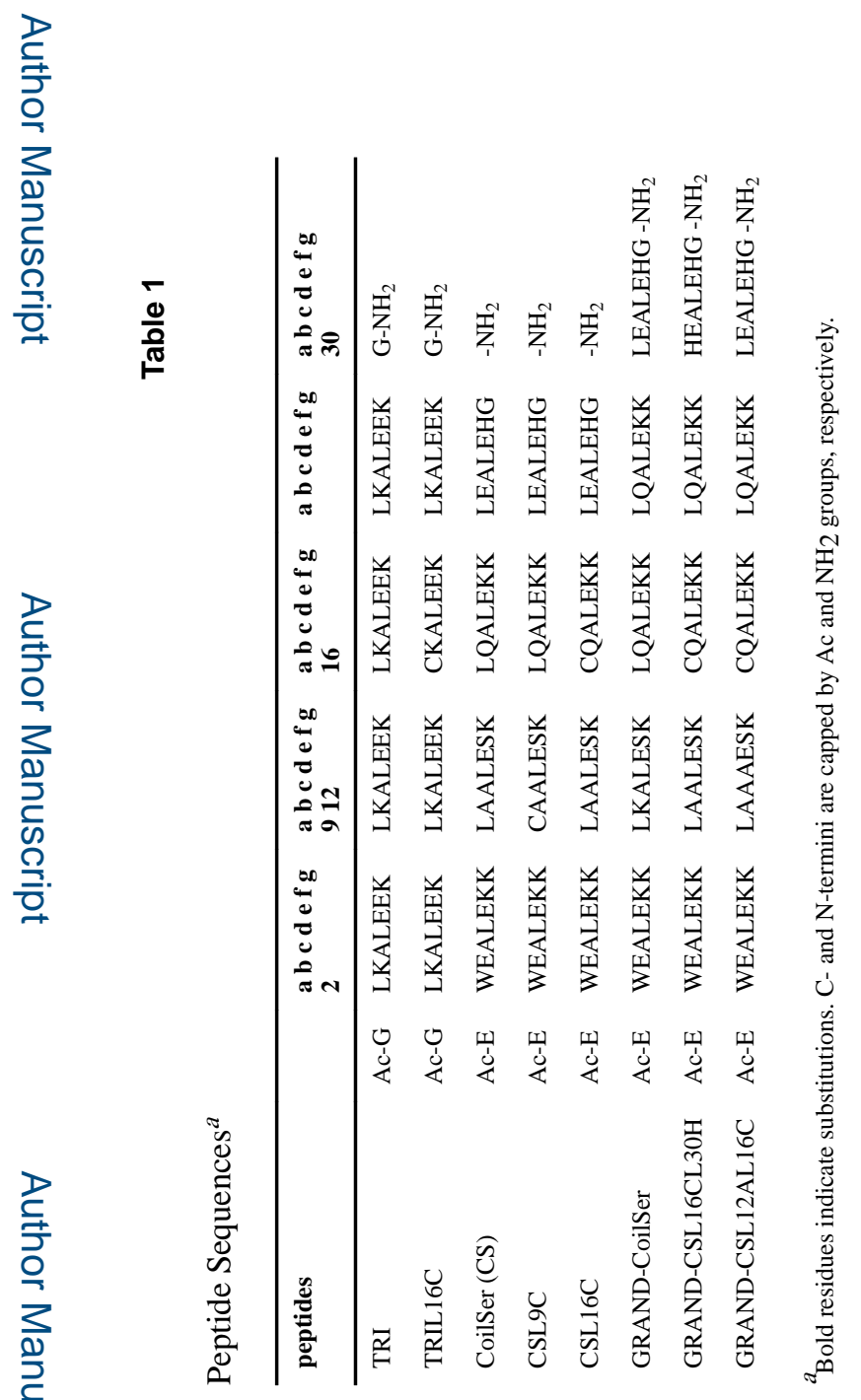




\section{Table 2}

Crystallographic Parameters Determined from the Crystal Structures ${ }^{a}$

\begin{tabular}{|c|c|c|c|c|}
\hline peptides & apo-(CSL16C) $)_{3}$ & $\mathrm{Hg}(\mathrm{II})_{\mathrm{S}} \mathrm{Zn}(\mathrm{II})_{\mathrm{N}}(\mathrm{GRAND}-\mathrm{CSL16CL30H})_{3}{ }^{+}$ & $\mathrm{Pb}(\mathrm{II})_{\mathbf{S}} \mathrm{Zn}(\mathrm{II})_{\mathbf{N}}(\mathrm{GRAND}-\mathrm{CSL16CL30H})_{3}{ }^{+}$ & Zn(II)(GRAND-CSL12A16C \\
\hline \multicolumn{5}{|l|}{ 16Cys Rotamers } \\
\hline$\chi_{1}$ (interior rotamers) $b$ & $-66.24^{\circ}$ (average) & $-150.35^{\circ}$ & $-68.34^{\circ}$ & $-149.39^{\circ}$ \\
\hline $\mathrm{S}_{\gamma}-\mathrm{S}_{\gamma} \operatorname{distance}^{c}(\AA)$ & 3.32 (average) & 4.08 & 3.45 & 3.92 \\
\hline$\chi_{1}$ (exterior rotamers) & $-176.47^{\circ}$ (average) ${ }^{f}$ & $-169.58^{\circ}$ & $-153.84^{\circ}$ & $172.63^{\circ}$ \\
\hline $\mathrm{S}_{\gamma}-\mathrm{S}_{\gamma}$ distance $^{d}(\AA)$ & 5.33 (average) ${ }^{g}$ & 5.06 & 4.66 & 5.91 \\
\hline \multicolumn{5}{|l|}{ Metal Site } \\
\hline \multirow[t]{2}{*}{ M-S bond length $(\AA)$} & & $2.38, \mathrm{Hg}(\mathrm{II})-\mathrm{S}$ & $2.60, \mathrm{~Pb}(\mathrm{II})-\mathrm{S}$ & $2.27, \mathrm{Zn}(\mathrm{II})-\mathrm{S}$ \\
\hline & & & & $2.18, \mathrm{Zn}(\mathrm{II})-\mathrm{O}$ \\
\hline \multirow[t]{2}{*}{ S-M-S angle (average) } & & $118.50^{\circ}$ & $84.58^{\circ}$ & $119.30^{\circ}, \mathrm{S}-\mathrm{Zn}(\mathrm{II})-\mathrm{S}$ \\
\hline & & & & $94.80^{\circ}, \mathrm{S}-\mathrm{Zn}(\mathrm{II})-\mathrm{O}$ \\
\hline distance of metal from & & -0.30 & -1.63 & +0.20 \\
\hline \multicolumn{5}{|l|}{$\begin{array}{l}\text { the bound Cys plane }{ }^{e} \\
(\AA)\end{array}$} \\
\hline \multicolumn{5}{|c|}{ Interlayer Space around the Metal Site $(\AA)$} \\
\hline $\begin{array}{l}\text { between 12Leu and } \\
16 \text { Cys }\end{array}$ & 4.92 & 5.92 & 4.45 & \\
\hline $\begin{array}{l}\text { between } 16 \text { Cys and } \\
\text { 19Leu }\end{array}$ & 4.41 & 3.30 & 4.65 & 3.23 \\
\hline \multicolumn{5}{|c|}{$\begin{array}{l}\text { a Peptides that were crystallized in } R 32 \text { space group have crystallographically imposed } 3 \text {-fold symmetry along the } z \text { axis that runs through the } \\
\text { center of the three helices of the } 3 \mathrm{SCC} \text {. The consequence of symmetry is that structures in } R 32 \text { will have a single reported value for the following } \\
\text { crystallographic parameters ( } \chi 1 \text { dihedral angles, atomic distances, and M-S distances), while average values are usually given for the structure } \\
\text { crystallizing in } \mathrm{C} 2 \text { in which the three helices are independent. }\end{array}$} \\
\hline \multicolumn{5}{|c|}{${ }^{b} \chi^{1}$ of Cys residue is determined from the dihedral angle of $\mathrm{N}-\mathrm{C} a-\mathrm{C} \beta-\mathrm{S} \gamma$. } \\
\hline \multicolumn{5}{|c|}{$c$ Distance determined between $\mathrm{S} \gamma$ atoms of the interior Cys conformers of two adjacent chains. } \\
\hline \multicolumn{5}{|c|}{$d$ Distance determined between $\mathrm{S} \gamma$ atoms of the exterior Cys conformers of two adjacent chains. } \\
\hline \multicolumn{5}{|c|}{ Plus sign (+) indicates the metal is situated above the bound Cys plane; minus (-) indicates the metal is situated below the bound Cys plane. } \\
\hline \multicolumn{5}{|c|}{${ }^{f}$ Averaged $\chi 1$ dihedral angle determined from minor Cys conformers observed from two of the chains. } \\
\hline
\end{tabular}

